\title{
How Do Exporters Cope With Violence? Evidence from Political Strikes in Bangladesh*
}

\author{
Reshad N. Ahsan ${ }^{+}$ \\ University of Melbourne
}

\author{
Kazi Iqbal ${ }^{\ddagger}$ \\ Bangladesh Institute of Development \\ Studies
}

November, 2016

\begin{abstract}
We examine the impact of widespread political strikes on the export-oriented garments industry in Bangladesh. To do so, we use the universe of political strikes and export transactions in Bangladesh during 2010 to 2013. These strikes represent uniquely targeted episodes of violence that allow us to identify its effect on exports through the transport disruption channel alone. Our results suggest that these strikes do not have a cumulative effect on a firm's decision to export or the value of its exports. Instead, they increase the cost of transporting shipments to the port by 69 percent. Thus, our results identify an additional cost of political violence that has been underexplored in the literature. Further, our results suggest that ensuring that political violence only disrupts transportation and not production may be an effective way to shield exporters in other developing countries from the adverse effects of such violence.
\end{abstract}

Keywords: Political Violence, Exports, Garments.

JEL Codes: D74, F14, O14

\footnotetext{
* We thank Arpita Chatterjee, Shahe Emran, Fahad Khalil, and seminar and conference participants at the Australasian Development Economics Workshop, the University of Melbourne, and the University of New South Wales for helpful comments and suggestions. Mahbuba Khatun and Amin Bin Hasib provided excellent research assistance. We gratefully acknowledge funding from the International Growth Centre for this project. The standard disclaimer applies.

+ Department of Economics, University of Melbourne 3010, Victoria, Australia; email: rahsan@unimelb.edu.au.

${ }^{\ddagger}$ E-17 Agargaon, Sher-e-Bangla Nagar, Dhaka 1217, Bangladesh; email: kiqbal@bids.org.bd.
} 


\section{Introduction}

In this paper we examine the impact of widespread political violence on Bangladeshi garments exporters. As in many other developing countries, democracy in Bangladesh is characterized by a culture of confrontational politics. ${ }^{1}$ A particularly egregious example of this is the use of political strikes, which are known locally as hartals. These hartals disrupt the country's transportation network and are typically used by opposition parties to pressure the government to accept its demands. In contrast to a recent literature that documents the adverse effects of such violence on trade, we show that hartals do not have a negative overall effect on the probability of exporting and the value of goods exported. Instead, we find that Bangladeshi exporters adjust to the disruption caused by hartals by reallocating shipments to non-hartal days. In fact, the vast majority of exporters in our sample continue to export during a hartal despite the added transport cost of doing so. Our calculations suggest that this added transport cost, which can be as high as 69 percent above the transport cost on a non-hartal day, is the main way in which hartals adversely affect exporters. Thus, we identify a cost of political violence that has been underexplored in the existing literature. ${ }^{2}$

To examine the impact of hartals on export behavior, we collect daily data on all hartals in Bangladesh during our sample period. Further, we also collect data on when a hartal was announced, why it was announced, whether it spanned a single day or multiple days, and the number of injuries and deaths during each hartal. Such detailed data on political violence in a developing country over an extended period of time are rare. The richness of our hartal data allow us to examine the heterogeneous effects of hartals based on its length and the notice provided to firms. It also allows us to evaluate the reasons for announcing a hartal and examine the extent to which the timing of this announcement is exogenous to economic factors. We pair our hartal data with the universe of export transactions in Bangladesh during our sample period of 2010 to 2013. These data, which are collected by the National Board of Revenue, allow us to construct an exporter-level, daily panel.

\footnotetext{
${ }^{1}$ Strauss and Taylor (2009) show that 19 percent of elections in Sub-Saharan Africa during the period 1990 to 2007 were marred by serious incidents of electoral violence. A further 39 percent of elections during this period experienced less severe electoral violence.

2 It is worth pointing out that the intensity of the violence that we examine in this paper differs from the violence examined in the previous literature, which typically examines the impact of civil wars or episodes of severe electoral violence (Collier and Duponchel, 2012; Ksoll, Machiavello, and Morjaria, 2014). Unlike these forms of violence, hartals are relatively "low intensity". For instance, during the period 2010 to 2013, there were 2 deaths per hartal in Bangladesh. Note, however, that with approximately 25 hartals a year during this period, this amounts to 50 deaths per year due directly to hartals.
} 
We use these data to examine the impact of a hartal on the timing of a firm's decision to export, the value of its shipments, and its decision to use air transport. Our baseline event window begins the day before each hartal and ends six days after it. This means that, not only are we able to examine the impact of a hartal on the day of a hartal itself, we are also able to examine an exporter's adjustment behavior on the days immediately before and after a hartal. Thus, a key advantage of our setting is that our high-frequency data allow us to precisely understand the manner in which exporters adjust over a short event window around a hartal. Our use of a short event window is essential because the median hartal in our data was announced with three days' notice. Thus, if exports do engage in any adjustment behavior, it will be during a short period around a hartal.3,4

A second advantage of our setting is that the targeted nature of hartals allows us to cleanly isolate a single channel (transport disruptions) through which such political violence affects exporters. As discussed in greater detail below, the typical study in the literature examines the economic impact of either a war, internal conflict, or intense political violence. The drawback of utilizing such episodes of severe violence is that they can affect economic activity through many channels such as transport disruptions, damage to utility infrastructure, damage to factories, and worker absenteeism. In contrast, the hartals that we examine in this paper are targeted towards disrupting transport networks alone. There is no direct damage to infrastructure and factories. Further, the mainly female garments workers in Bangladesh live near their factories. As a result, there is very little worker absenteeism as a result of a hartal (Ashraf et al., 2015). Thus, hartals provide a uniquely "clean" shock that is free of other confounding factors and allow us to isolate the effect of political violence on exporters through the transport disruption channel alone.

Our results suggest that a hartal lowers the probability that a firm in our sample will export on that day by 1.20 percentage points. However, we also find that a hartal leads to a 0.70 percentage point increase in the probability that a firm will export on the day before. In fact, over our eight-day event window, we find that there is no cumulative effect of a hartal on the probability that an exporter

\footnotetext{
${ }^{3}$ The average exporter in our sample makes approximately 93 shipments a year with an average gap between shipments of about 6 days. Thus, they ship at a sufficiently high frequency such that an eight-day event window is long enough for us to observe their adjustment behavior.

${ }^{4}$ The need for a short event window validates our decision to focus on exports rather than production. While high-frequency export data for a large number of firms are now available for several countries (see for example the data used in Eaton, Kortum, and Kramarz, 2011), this is not the case for high-frequency production data. A notable exception to this are the data used by Ashraf, Machiavello, Rabbani, and Woodruff (2015), although their data only cover 33 factories.
} 
in our sample will make a shipment. These results suggest that some exporters in our sample reallocate their shipments away from hartal days to minimize the risk of its shipment being damaged due to the violence. We observe this adjustment behavior in both small and large exporters as well as exporters with and without an extensive export history. Further, these results are robust to including exporter fixed effects, to controlling for daily, international shipping prices, and to the use of alternate controls for seasonality. Our findings suggest that the vast majority of exporters in our sample continue to export during a hartal despite the added transport cost of doing so. We use a simple framework to show that the cost of transporting goods to the port during a hartal is 69 percent higher than the cost on a non-hartal day.

Next, we exploit the richness of our data to examine whether the duration of a hartal matters. We find that while hartals that span a single day do not have a disruptive effect, hartals that span between two to four consecutive days lead to a cumulative decrease in the probability of making an export shipment. We also examine whether hartals affect the value of shipments made by the exporters in our sample. Our concern here is that the transport disruptions caused by hartals may lead to foreign retailers cancelling orders. Alternatively, these disruptions may lead to local garments exporters sending smaller shipments to their buyers. In both cases, the value of exports for the average firm may decrease during our eight-day event window. However, our results suggest that this is not the case. Lastly, we examine whether the exporters in our sample cope with the disruptions caused by hartals by using the more expensive air transport. Our results suggest that the average exporter in our sample is more likely to use air transport on the day of a hartal, although they compensate for this by lowering the use of air transport on the days following a hartal. As a result, over the entire event window, there is no cumulative effect on the probability of using air transport.

Taken together, our results suggest that some Bangladeshi garments exporters cope with the disruptions and risks associated with hartals by reallocating shipments away from hartal days and by increasingly using air shipment on the day of the hartal itself. The vast majority of exporters continue to ship during a hartal despite the higher transport cost and risk of damage to their shipments. These findings are important for two key reasons. First, our results suggest that the main cost of such political violence is the additional transport costs borne by exporters that continue to export during the violence. This is a cost of political violence that has been underexplored in the literature. 
Second, while hartals are specific to Bangladesh, political violence is not. Thus, our results contain important insight for policy makers in other developing countries that seek to attenuate the adverse effect of such violence on their exports. Because we are able to isolate the effect of political violence on exporters through the transport disruptions channel alone, we can conclude that the transport disruptions caused by such violence does not have a first-order effect on an exporter's ability to make its shipment. Exporters are sufficiently adaptable an can engage in adjustment behavior to minimize delays to their shipments. The distinguishing feature of hartals in Bangladesh is that it does not disrupt an exporter's production. This violence does not damage factories or lead to worker absenteeism. This suggests that preventing political violence from disrupting production is likely the key factor in attenuating its adverse effects on firms in developing countries.

Our paper is related to a growing literature that documents the adverse, microeconomic effects of political violence on firms. A pioneering paper in this literature is Ksoll, Machiavello, and Morjaria (2014), who use daily export data to examine the impact of election-related violence in 2008 on Kenya's floriculture industry. They find that weekly export values in affected regions decreased by 38 percent. They then use self-reported, recall data to show that worker absenteeism, and not transportation problems, was the key mechanism driving their results. As mentioned above, the key distinguishing feature of our paper is that we examine a form of political violence that is targeted towards disrupting transport networks. As a result, we are able to cleanly isolate the effect of political violence on exporters that operates through this channel alone.

Our paper is also related to a literature that examines the impact of political violence and instability on other aspects of firm performance. For instance, Shonchoy and Tsubota (2015) use annual, firm-level data to show that hartals in Bangladesh lower firm productivity. Machiavello and Morjaria (2015) examine how election-related violence affected the relationship between Kenyan flower exporters and its foreign buyers. Collier and Duponchel (2012) examine how the greater intensity of fighting in Sierra Leone affects firm output. Similarly, Guidolin and La Ferrara (2007) and Abadie and Gardeazabal (2003) examine how the sudden end of civil conflict in Angola and a truce announced in the Basque region of Spain respectively affected the stock-market returns of firms operating in these regions.

Next, our paper is also related to an earlier literature that examines the effect of terrorism and conflict on bilateral trade (Nitsch and Schumacher, 2004; Blomberg and Hess, 2006; Martin, Mayer, 
and Thoenig, 2008; Glick and Taylor, 2010). ${ }^{5}$ It is also related to a literature that documents the negative effect of political instability on growth (Alesina, Özler, Roubini, and Swagel, 1996) and to a literature that explores the use of violence to influence elections (Ellman and Wantchekon, 2002; Chaturvedi, 2005, Collier and Vicente, 2012). Finally, our paper is related to a literature that documents the trade-reducing effects of transportation delays (Djankov, Freund, and Pham, 2010; Hummels and Schaur, 2013) and to a literature that uses natural disasters to identify the causal effect of transport disruptions on trade (Volpe Martincus and Blyde, 2013; Besedes and Murshid, 2015). ${ }^{6}$

We structure the remainder of the paper as follows. In section 2 we provide some background on hartals in Bangladesh as well as on its export-oriented garments industry. In section 3 we describe our hartal data and discuss the evolving nature of these hartals during our sample period. We also discuss our export data in this section. In section 4 we introduce our econometric specification and discuss some econometric issues that we address. In section 5 we describe our results and robustness checks. Finally, in section 6 we provide a conclusion.

\section{Background}

\subsection{Hartals in Bangladesh}

A hartal is a political protest that has a long history in both Bangladesh as well as in South Asia. For instance, hartals were first used as early as 1919 by Mahatma Gandhi as a voluntary and largely non-violent method of civil disobedience against British colonial rule. ${ }^{7}$ In Bangladesh's preindependence period (1947 to 1971), hartals were seen as a legitimate method of protest against misrule by West Pakistan. As a result, hartals during this period had relatively greater popular support. Next, in the 1980 's, hartals were used to protest the authoritarian, military ruler at the time and also enjoyed widespread support. This historical success and popular support lends

\footnotetext{
${ }^{5}$ The relationship between economic globalization and conflict has also been extensively studied by political scientists. See the papers cited in Barbieri and Reuveny (2005). See also Blattman and Miguel (2010) for a survey of studies that examine the broader economic impact of conflict.

${ }^{6}$ These natural disasters provide exogenous shocks to transport infrastructure and therefore address endogeneity concerns in an innovative manner. However, its use has the drawback that natural disasters are a rare type of transport disruption. As a result, they do not necessarily inform us about how exporters respond to less intense and more common disruptions such as poor weather, inadequate infrastructure etc. In contrast, our results based on low-intensity and targeted disruptions are a better guide to how exporters in developing countries respond to the typical transport disruptions that they face.

${ }^{7}$ A related form of protest is prevalent in India and Nepal today, where they are referred to as bandhs.
} 
contemporary hartals a degree of legitimacy in the eyes of Bangladeshi political parties (Suykens and Islam, 2013).

While Bangladesh has a tradition of using hartals to protest misrule, in recent years its use has become more widespread. This is because, despite being a parliamentary democracy since 1991, Bangladesh's democracy is characterized by a general intolerance for the views of the opposition parties. As a result, institutional mechanisms for addressing the grievances of opposition parties either do not exist or do not work well. In the Bangladeshi context, the main grievance is regarding the fairness of general elections. As in the case in other illiberal democracies, opposition parties in Bangladesh do not trust the incumbent to hold fair elections. As a result, hartals are viewed as the only viable way to force the incumbent to either enact electoral reforms or to resign and allow a neutral government to hold fair elections (Sobhan, 2004a).

Despite its past history of popular support, it is the case that hartals today are deeply unpopular among ordinary Bangladeshis. A 2013 poll conducted jointly by the Asia Foundation and a local newspaper found that 31 percent of all respondents considered hartals and political violence to be the country's leading problem (Daily Star, 2013a) So why do political parties use them? There are three main reasons. First, a successful hartal sends a signal to the government that the opposition party is sufficiently powerful and organized and poses an electoral threat to the government. It is the typically the case that other non-violent political activities such as processions, meetings, etc. are also scheduled to coincide with a hartal. As a result, a hartal is seen as a tool with which to regroup opposition political activists and to place pressure on the incumbent government to accept the opposition's demands. Second, Bangladeshi politics is dominated by two main political parties: the Awami League and the Bangladesh Nationalist Party. This duopoly engenders a belief that the voter will not punish opposition parties that call hartals since their choice is between the opposition and a typically unpopular incumbent (Sobhan, 2004a). ${ }^{8}$ Moreover, both political parties have built a sizeable base of loyal supporters. This means that the probability of losing significant political support as a result of staging a violent hartal is low. Lastly, given the typical heavy-handed response by police, hartals are viewed by opposition parties as an effective method with which to garner greater voter support (Sobhan, 2004b). As described below, a common tactic adopted by opposition activists during a hartal is to goad the police into violent confrontations. The resulting response by

\footnotetext{
${ }^{8}$ This is supported by the observation that in all four general elections held in Bangladesh in which both parties participated, the opposition used hartals extensively prior to the election and was still voted to office.
} 
police, which typically involves the use of excessive force, generates widespread sympathy for injured opposition activists.

So what happens during a hartal? As described in greater detail in Ahmed and Mortaza (2005), hartals are enforced by activists that include armed mercenaries along with hired protestors. The latter are typically drawn from various urban slums. The main aim of these activists is to restrict vehicular movement in key urban areas. This is done in three ways. First, the armed activists goad the police into violent confrontation. Second, hartal activists set off homemade grenades and other improvised explosives at various urban areas (Human Rights Watch, 2014). Finally, a third tactic used by opposition activists is to torch vehicles (private cars, buses, vans etc.) that ignore the hartal restrictions and are seen on city streets. ${ }^{9}$ These activities typically start the night before the hartal itself and its aim is to create a sense of fear among everyday citizens and entrepreneurs and to discourage them from using motor vehicles. Importantly, because hartals are most strictly enforced in urban areas away from industrial zones, there is typically no damage to factories or to utility infrastructure. Thus, as documented in greater detail below, apart from the transport disruption, factories are otherwise unaffected.

\subsection{The Ready-Made Garments Industry in Bangladesh}

The disruptions caused by hartals are particularly problematic for the export-oriented, readymade garments industry (RMG or garments from here on) in Bangladesh. This industry has played a vital role in driving the country's recent economic growth. It emerged in the late 1970's through a partnership between a local firm, Desh Ltd., and a South Korean manufacturer, Daewoo Corporation. At the time, the low export of garments from Bangladesh meant that it was not subject to quotas in Western markets. Daewoo's objective was to use Bangladesh as an export platform to circumvent the quotas that applied to its exports from South Korea. According to Quddus and Rashid (2000), as part of this venture, Desh sent 130 of its employees to South Korea to participate in an eight-month training program. The vast majority of these employees then went on to start their own garments factories. From this humble beginning, the garments industry in Bangladesh has grown at a dramatic

\footnotetext{
${ }^{9}$ It is evident that to successfully stage a hartal, where success is measured by the amount of disruption caused, opposition parties need to have the organizational capacity to hire a sufficient number of armed activists and other individuals. This work is typically the responsibility of mid and low-level party operatives. Demonstrating competence in organizing disruptive hartals is considered by these party operatives to be highly valuable as it often leads to patronage if the party is voted to government. As a result, hartals tend to be very popular among such operatives (Suykens and Islam, 2013).
} 
rate over the last four decades (Heath and Mobarak, 2015) and has emerged today as one of the leading garments exporters in the world. According to McKinsey (2011), Bangladesh's garments sector in 2011 employed around 3.60 million workers, most of whom were women.

During this period in which the garments sector in Bangladesh has expanded, the nature of garments sourcing has changed dramatically. Traditional garments sourcing methods resulted in orders being placed by Western retailers to overseas factories approximately six months before a season in the West (Birtwistle, Siddiqui, and Fiorito, 2013). The size of the orders was forecasted based on sales from previous years. Errors in these forecasts created a mismatch between the demand for an item and its available stock in retail outlets. In particular, such errors meant that items that turned out to be popular were understocked while unpopular items were overstocked.

To lower such inefficiency, an increasing number of Western garments retailers switched to quick-response (QR) methods of supply-chain management starting in the 1990's (Taplin, 2014). QR methods are designed to reduce the gap between when an order is placed to factories and the date at which the customer purchases the item. A lower gap allows retailers to better predict what the trendy items are likely to be in any given season. It also means that once it becomes evident that an item is popular, retailers can quickly order a new batch from its supplier. The use of QR methods meant that the typical order to an overseas supplier changed from having a predictable several-month lead time to a series of small and frequent orders with low lead times that better reflect real-time demand. 10,11 While QR methods lower costs for retailers and prices for consumers, it places a greater strain on suppliers as they have to be flexible enough to respond to volatile changes in fashion trends. QR methods also place a greater emphasis on timely delivery as any delays may cause popular items to be understocked in retail stores.

The discussion above suggests that in short lead-time industries such as garments, disruptions due to hartals can be particularly costly. However, we also know that hartals are not a recent phenomenon in Bangladesh. This raises the possibility that exporters have fully adapted to the

\footnotetext{
${ }^{10}$ Lead time is defined in this context as the gap between an order date and the required delivery date.

${ }^{11}$ QR methods are used both by retailers that extensively use overseas suppliers as well as those that do not. For instance, a pioneer of these methods in fashion retail is the Spanish retailer Inditex (owner of Zara). Inditex typically completes its design, produce, and deliver cycle in 15 days (Ferdows, Lewis, and Machuca, 2004). It has a system where it exercises greater control of its supply chain with comparatively low reliance on overseas suppliers. In contrast, the Swedish retailer H\&M also uses QR methods but does not own any factories. In fact, 75 percent of its suppliers are based in Asia (Taplin, 2014).
} 
potentially disruptive effects of hartals and that they no longer pose a problem to them. There are three pieces of evidence that suggest otherwise. First, survey data indicate that firms in Bangladesh do consider hartals to be a constraint. For instance, the 2013 round of the Enterprise Surveys collected by the World Bank asked Bangladeshi firms to what extent political instability was an obstacle to them. These responses suggest that 97.80 percent of firms report political instability to be an obstacle. In fact, 69.90 percent report political instability to be either a major or severe obstacle. ${ }^{12}$

Second, a survey of chief purchasing officers (CPO) of several European and US apparel retailers conducted by McKinsey suggest that political instability is one of the five main challenges to the growth of garments exports in Bangladesh (McKinsey, 2011). Approximately half of these CPO's report that they will decrease their sourcing from Bangladesh if political instability were to increase, as such instability leads to greater delays. Third, existing efforts to estimate the economic costs of hartals all suggest that they pose a significant economic burden. For instance, a 2013 report from the Dhaka Chamber of Commerce and Industry suggests that a hartal causes an approximately USD 200 million loss to the economy and a USD 45 million loss to the garments industry (Daily Star, 2013b). Similarly, a report from the United Nations Development Programme (UNDP) suggests that hartals lead to an estimated loss of 3-4 percent of Bangladesh's GDP (Khundker, 2005).

\subsection{The Disruptive Effect of Hartals}

An important feature of hartals is that, while they are costly to exporters, these costs are almost only due to transport disruptions. By making motor vehicle movement more risky, hartals are likely to lead to higher transport prices to compensate transport companies for the added risk they bear. They are also likely to lead to longer transit times as drivers avoid violence-prone areas in cities. Finally, there is also a non-negligible probability of shipment loss in the event that a shipment is damaged or destroyed by political activists.

In contrast, at least in the garments industry, the mainly female workforce tends to live very close to their place of work. As a result, hartals do not make it significantly more costly for these workers to travel to their factory. This is supported by the results in Ashraf et al. (2015) who find that

\footnotetext{
${ }^{12}$ The Enterprise Surveys do not ask firms specifically about hartals. However, given that hartals are most prevalent immediately before elections and they are the most disruptive manifestation of political instability in Bangladesh, we treat a firm's response to this question as a reasonable gauge of their views on the extent to which hartals are an obstacle to them.
} 
hartals do not affect worker absenteeism or productivity in garments factories. Hartals also do not adversely affect port operations for export shipments. While precise data regarding this are difficult to find, media reports suggest that any adverse effects on port operations are restricted to the import side (Haroon, 2012). On a typical day, an imported container is offloaded from a ship and then placed on a truck for transport to the relevant factory. During a hartal, these containers are placed in port storage as trucks are less able to transport them to the factories. In contrast, if a container intended for export is already in the port premises on the day of a hartal, they are loaded on to ships. The delay in export shipments occur due to the inability of some shipments to reach the port itself during a hartal.

The discussion above assumes that the time to transport goods from the factory to the port is sufficiently long such that transport disruptions are costly. If instead the time needed to transport goods to the port was very short, then the disruptions caused by a hartal may not significantly affect the transport cost or time for an average exporter. Unfortunately the export data that we use do not record the location of each exporter's factory. As a result, we cannot use these data to calculate an exporter's transport time or distance from the factory to the port. Instead, to gauge the location of export activity, we use the results from Fernandes (2008). She shows that 67 percent of garments firms in her sample are located in either Dhaka or the Dhaka Export Processing Zone. Next, our export data, which are described in detail below, suggest that 73.68 percent of garment export shipments are made through Chittagong port, which is located in the south east of the country. Thus, the majority of exporters, who are located near Dhaka, ship their goods through Chittagong port. The distance between Dhaka and Chittagong Port is approximately 263 kilometres. On a typical day, it can take a truck up to 24 hours to reach Chittagong Port from a factory in Dhaka. ${ }^{13}$ It follows that, for the majority of exporters in our data, we can rule out the possibility that the transport disruption caused by hartals represents a trivial additional cost.

\footnotetext{
${ }^{13}$ Both the distance between Dhaka and Chittagong Port and the travel time are based on Doing Business 2016 data produced by the World Bank.
} 


\section{Data}

\subsection{Hartal Data}

To examine the effects of hartals on export behavior, we compiled a database of hartals during the period 2005 to 2013 using the two most popular Bengali and English language daily newspapers in Bangladesh. These are The Daily Ittefaq and The Daily Star respectively. We used two research assistants, who independently went through the archives of these newspapers for each day of our sample period to collect information on hartals. In order to avoid data collection errors, we then compared the entries of both research assistants and corrected any discrepancies. Apart from collecting the date on which the hartal occurred, we also collected the announcement date of the hartal, the length of the hartal, the political party/parties announcing the hartal and the official reason for announcing the hartal. Our data yield the following stylized facts about hartals in Bangladesh.

\section{Hartals Are Mainly Timed Around Elections}

Figure 1 illustrates the annual trend in hartals during the period 2005 to 2013. In the first half of this time period (2005 to 2009), there were a total of 53 hartals in Bangladesh. The prevalence of hartals during this period reached its peak immediately before the general elections that were scheduled for 22 ${ }^{\text {nd }}$ January, 2007. In the face of increasingly violent unrest, the Bangladeshi military intervened on $11^{\text {th }}$ January, 2007 and installed a military-backed caretaker government. This government remained in power until the general elections held on $29^{\text {th }}$ December, 2008. As Figure 1 illustrates, this period of military-backed rule was free from hartals. In the second half of this period (2010 to 2013), there were 99 hartals in Bangladesh. As before, the prevalence of hartals again increased during the year preceding the general elections that were held on $5^{\text {th }}$ January, 2014..$^{14}$

\section{Hartals Have Become Increasingly Disruptive}

Next, as Table 1 demonstrates, not only have hartals become more frequent during the second half of this period, they have also become more intense. When announcing a hartal, a political party can stipulate whether the hartal is going to be span a single day or whether they will span multiple days. Our data suggest that the percentage of single-day hartals decreased significantly during the

\footnotetext{
${ }^{14}$ Over the entire 2005 to 2013 period there were approximately 17 hartals per year. This is almost the same as the number of public holidays per year (19).
} 
second half of our sample period. For instance, during the period 2005 to 2009, 72 percent of hartals spanned a single day while 14 percent spanned two-days and 14 percent spanned more than two days. In contrast, during the period 2010 to 2013, 60 percent of hartals spanned a single day, 21 percent spanned two days, and 19 percent spanned more than two days. Parties that announce a hartal can also stipulate the number of hours during which the hartal will apply. Our data suggest that the average length of hartals increased from 14.60 hours during the first half of the sample period to 16.13 hours during the second half.

Further, the hartals in the second half of our sample period were also announced with less notice. For instance, during the period 2005-2009, hartals were announced 7.28 days before the hartal itself. However, during the period 2010-2013, hartals were announced 4.62 days before the hartal itself. In fact, the median gap between the announcement date and the hartal date was three days during the second half. Lastly, during the first half of our sample period, there were about 0.5 deaths per hartal whereas in the second half, there were about two deaths per hartal. Thus, along all dimensions reported in Table 1, hartals have become more disruptive in Bangladesh in recent years.

\subsection{Transaction-Level Export Data}

We combine our hartal database with transaction-level export data. These administrative data represent the universe of export transactions during our sample period and are collected by the National Board of Revenue (NBR). These data were digitized using the Automated System for Customs Data designed by the United Nations Conference on Trade and Development (UNCTAD). The NBR records the bill of entry details associated with each export shipment. These bills of entry provide the date of an export shipment, the exporters' unique identification number, the total value of export, the 8-digit HS code of the product that is exported, the port through which the product is exported, and the destination of the export shipment. As a result, we can use these data to construct a panel of export transactions during the period 2005 to 2013. To construct our working sample, we omit observations that do not include the date of export (0.0005 percent of the raw data). We then aggregate each firm's export by day. In some cases, firms have multiple consignments on the same 
day, often for the same product. ${ }^{15}$ We aggregate these to ensure that there is only one observation per firm per day.

To gauge the reliability of these data, we compare the aggregate exports calculated from our customs data with that reported by the World Bank. This comparison is demonstrated in Table 2. In both columns (1) and (2) we report the total annual exports from Bangladesh for the period 2005 to 2013. In column (1) we use the customs data while in column (2) we use the World Bank data. In column (3) we report the ratio of annual exports from the customs data to the annual exports from the World Bank data. Over the entire sample period, this ratio takes the value of 0.995 . Thus, over this entire period, the customs data accurately captures almost all export transactions from Bangladesh. However, if we examine this ratio by year, certain anomalies become evident. In particular, the ratios in 2006 and especially 2007 are outliers. In fact, the customs data suggest that there was a decrease in exports in 2007, which is surprising given the widely reported inexorable rise of exports in Bangladesh during this period. Due to these concerns about data quality, we chose to restrict our working sample to the period 2010 to $2013 .{ }^{16}$ Lastly, we also restrict the sample to firms in the readymade garments industry. During our sample, ready-made garments exports represented 79.40 percent of all Bangladeshi exports and ready-made garments exporters represented 76.31 percent of all Bangladeshi exporters.

In Table 3 we report some descriptive statistics of the exporters in our working sample. This sample consists of 8,161 garments firms that have exported at least once during our sample period of 2010 to $2013 .{ }^{17}$ On average, 624 firms export on any given day. The average exporter in our sample exports 5.41 products per year, where a product is defined at the HS6 level. Such a firm also exports to 5.40 destinations per year and makes 92.75 shipments per year. The average firm in our sample uses air transport for 22 percent of its shipments. Thus, our sample consists of high-frequency, multi-

\footnotetext{
${ }^{15}$ We define a shipment as the value of goods that a firm exports on a given day. In contrast, we define a consignment as the value of goods reported in each bill-of-entry. To make this clearer, suppose that an exporter is planning to export 1,000 units of a product on a given day. She decides to transport them to the port in four trucks consisting of 250 units per truck. In our analysis, each truck is considered a consignment while the total quantity exported on that day $(1,000)$ is the shipment.

${ }^{16}$ An alternate approach would be to include 2008 and 2009, which consists of 6,380,879 observations (8,777 firms $\times 727$ days). However, as Figure 1 illustrates, there were no hartals during these two years. This means that adding these years will increase our sample size by almost 6.38 million observations without adding any additional variation to our hartal variables. Due to this, we chose to omit these years from our working sample.

${ }^{17}$ Thus, for each of these firms we have 1,453 daily observations during the period 2010 to 2013 . This excludes seven dates that are missing in our sample. These missing dates typically coincide with Eid, which is the main public holiday in Muslim-majority Bangladesh.
} 
product, and multi-destination exporters. Next, in Table 4 we report the five most common export products and destinations. The most commonly exported ready-made garments product is "cotton tshirts, singlets, and other vests", which accounts for 31.80 percent of all exports in our sample. This is followed by "men's or boy's cotton trousers", which accounts for 27.30 percent of all exports in our sample. The most common destination for these exports is the United States, which accounts for 29.93 percent of all exports. This is followed by Germany, which accounts for 24.96 percent of all exports.

\section{Econometric Strategy}

\subsection{The Timing of the Effect of Hartals on Exports}

Since hartals provide a transportation shock to Bangladeshi exporters, we would expect there to be a reduction in export shipments on the day of the hartal itself. What is less well understood is the lag structure with which hartals will affect the decision to export. To explore this, consider an exporter's operational phase, as illustrated below. This operational phase consists of two segments: (a) a production segment where the goods intended for export are produced and (b) a transportation segment where the goods intended for export are transported to the port. $t=0$ is the beginning of the operational phase and $t=T_{P}$ is the end of the production segment. The period between $T_{P}$ to $T$ represents the transportation segment.

\begin{tabular}{|c|c|c|}
\hline $\begin{array}{l}t=0, \text { production } \\
\text { starts }\end{array}$ & $\begin{array}{r}t=T_{P}, \\
\text { production ends }\end{array}$ & $\begin{array}{r}t=T \text {, goods } \\
\text { reach the port }\end{array}$ \\
\hline & & Transportation \\
\hline
\end{tabular}

As discussed above, hartals are a unique form of political violence because they are targeted towards disrupting transportation and do not cause any direct disruption to production. Thus, if a hartal falls on an exporter's production segment, then we should not observe a disruption to its production and therefore should not observe an effect on its probability of exporting or the value of 
its exports at day T.18 On the other hand, if a hartal falls on an exporter's transportation segment, an exporter's ability to transport its goods to the port in a timely manner will be adversely affected. As a result, the amount it exports on day $T$ will be reduced. It follows that the exports on day $T$ will only be affected by a hartal that is scheduled on day $T$ itself or by hartals on days within a short window before $T$. This will motivate the use of a relatively short event window in our econometric specification below.

\subsection{Econometric Specification}

To capture the impact of hartals on exports, we estimate the following specification:

$$
\operatorname{Pr}\left[X_{i t}>0\right]=\alpha_{1}+\sum_{s=-1}^{6} \beta_{s} H_{t-s}+\theta_{d}^{w}+\theta_{d}^{Y}+\theta_{y}+\varepsilon_{i t}
$$

where $X_{i t}$ is the value of total exports for exporter $i$ on day $t$. Our aim here is to capture whether an exporter responds to a hartal by the choosing not to export at all on a hartal day. Thus, the regression in (1) estimates the effect of a hartal on the extensive margin. To identify the effect on the intensive margin, we also use as a dependent variable a firm's total daily exports in natural logarithm. Lastly, to explore other coping mechanisms, we also replace the dependent variable in (1) with an indicator for whether a firm uses air transport on day $t$.

When $s=0, H_{t}$ is an indicator variable for whether there was a hartal on that day. For all other values of $s, H_{t-s}$ takes the value of one if there was a hartal $t-s$ days ago and there wasn't a hartal on day $t$. Thus, each coefficient $\beta_{s}$ captures the impact of a hartal that occurred $s$ days ago on today's exports. The use of lagged hartal indicators allows us to capture the extent to which exporter's reallocate their shipment away from hartal days and towards days immediately before and after a hartal. Thus, if such reallocation were absent we would expect $\beta_{s}$ to equal zero for all $s \neq 0$.

Our specification also extensively controls for any seasonal patterns in the data. In particular, we include day-of-week fixed effects $\left(\theta_{d}^{w}\right)$, which will capture any secular variation in exports during the week. We also include day-of-year fixed effects $\left(\theta_{d}^{Y}\right)$ to control for any seasonal factors that might be correlated with exports. For instance, exports for particular products might exhibit strong seasonal patterns during the year (e.g. summer or winter clothing). Thus, by not including day-of-year fixed

\footnotetext{
${ }^{18}$ If we do observe such long-lagged effects, it must be due to disruptions in access to imported inputs during the production segment.
} 
effects, our regression estimates might be picking up spurious changes in the data. Further, we include year fixed effects $\left(\theta_{y}\right)$ to capture macro-level factors that are correlated with hartals as well as a firm's export decision. Lastly, $\varepsilon_{i t}$ is a classical error term. ${ }^{19}$

In section 4.1 above, we discussed the rationale for examining a short event-window around a hartal. Nonetheless, our choice of an exact, eight-day event window ( $s=-1$ to $s=6)$ in our baseline specification merits further discussion. In choosing our baseline event window length, we faced the following trade-off. On the one hand, we do not want our event window to be too short as this will prevent us from capturing an exporter's full adjustment behavior. For example, a two-day event window won't allow us to capture an exporter's full adjustment behavior if this exporter responds to a hartal by shifting its export shipment to three days after the hartal. On the other hand, we do not want our event window to be too long as this will introduce other confounding factors. As discussed above, a hartal will only affect an exporter's export shipment with a long lag if it disrupts the exporter's access to imported inputs. Given that our aim here is to capture the direct effect of a direct disruption to export shipment alone, a relatively short event window is appropriate.

With this trade-off in mind, we take a data-driven approach to selecting a baseline event window length. In particular, we choose the minimum event window needed for the total effect of a hartal on the decision to export of an average firm to approach zero. This approach has the advantage that it allows us to be agnostic about the inherently difficult question of what is the "correct" event window length. Nonetheless, as discussed below, we show that our key results are robust to alternate event window lengths.

Finally, our choice of an eight-day event window requires that firms in our sample export at a relatively high frequency. If the typical shipment gap is greater than eight days then our event window may not be long enough to observe the adjustment behavior of firms. To examine whether this is the case, we plot the distribution of the number of days shipped per year in Figure 2. This figure suggests that the average exporter in our sample exports 92.75 days per year. Further, our data suggests that the average gap between shipment days is 6.29 days. Both of these numbers suggest

\footnotetext{
${ }^{19}$ Given that hartals are exogenous to the exporter, we are not concerned about the correlation between them and unobservable, time-invariant exporter characteristics. As a result, in the interest of parsimony, we do not include exporter fixed effects in our baseline specification. We do however include them as a robustness check. As we discuss below, adding the firm fixed effects does not change the key results of the paper.
} 
that the firms in our working sample export with relatively high frequency and therefore an eight-day event window is long for us to observe the adjustment behavior of firms.

\subsection{Econometric Issues}

Our identification of (1) relies on two key assumptions. The first is that hartals are not announced because of adverse economic shocks. To the extent that these adverse shocks also lower exports, this would result in us picking up a spurious negative correlation between hartals and exports. To examine whether this is the case, we explore the reasons for announcing a hartal. Recall that when we constructed our hartal database we recorded the official reason for announcing each hartal. We group these reasons into various categories and illustrate their frequencies in Figure 3. As this figure clearly demonstrates, the main reasons for announcing a hartal are political. The most common reason is a demand for election reforms. Since the beginning of electoral democracy in Bangladesh in 1991, elections there have been marred by distrust and violence. As a result, many preelection hartals are motivated by the desire for electoral reforms to minimize any advantage for the incumbent party. Other common reasons for announcing hartals are to protest police violence against opposition activists and to protest a recent War Crimes trial. Importantly, of the 99 hartals during our sample period, only four were motivated by economic factors. In all four cases, the motivation for announcing the hartal was the rising price of essential goods and, therefore, it was not directly related to exports.

While hartals may be announced due to political reasons, they may be timed around important economic periods. Thus, the second identifying assumption required for (1) is that the timing of hartals is not related to economic conditions. For instance, if particular months of the year represent peak exporting periods, opposition parties may refrain from announcing hartals then to minimize any adverse effect on exporters. To examine whether this is the case, we plot the share of exports by month and the share of hartals by month in Figure 4. As this figure illustrates, garments exports in Bangladesh are fairly evenly spread out throughout the calendar year. This is mainly a function of the fact that garments are in demand throughout the year. While the exact product to be exported will vary throughout the year (e.g. summer vs. winter clothing), the export of garments overall are unlikely to be specific to any seasons. In contrast, hartals are more prevalent at the end of the calendar year. This is because of two main reasons. First, elections in Bangladesh are typically held in January and February. Further, the dryer and cooler weather at the end of the year is more 
conducive to staging a hartal. ${ }^{20}$ For these reasons, hartals in Bangladesh peak around November and December. Thus, there is no evidence in Figure 4 of hartals being timed around peak export periods, mainly because the uniform nature of garments exports throughout the year in Bangladesh means that significant peak periods are non-existent.

\section{Results}

\subsection{Baseline Results and Event-Window Selection}

We begin by estimating equation (1) for various event windows using a linear probability model. Our aim here is to examine how the effect of a hartal evolves over various event windows and to pick the shortest event window needed for the cumulative effect of a hartal to approach zero. This shortest event window will then serve as our default event window for the rest of our analysis. This data-driven approach to selecting a default event window has the advantage that it does not require us to take a stand on what the default event window should be.

In column (1) of Table 5 we report the contemporaneous effect of a hartal. The dependent variable is an indicator that takes the value of one if a firm exports on day $t$ and is zero otherwise. The coefficient of the hartal indicator, $H_{t}$, is negative and statistically significant. It suggests that a hartal reduces the average firm's probability of exporting by 1.30 percentage points. ${ }^{21}$ In column (2) we include the first lead of the hartal indicator, $H_{t+1}$, which takes the value of one if there is hartal tomorrow but no hartal today. This indicator will capture the extent to which exporters bring forward their export shipment date to lower their exposure to a hartal. The results in this column suggest that the contemporaneous effect alone does not capture the true effect of a hartal on an average firm's export behavior. In particular, we find here that while there is 1.20 percentage point reduction in the probability of making an export shipment on the day of the hartal itself, there is a 0.80 percentage point increase in this probability the day before the hartal. That is, the average firm responds to a hartal by increasing its shipments the day before the hartal to make-up for some of the reduced shipments on the day of the hartal.

\footnotetext{
${ }^{20}$ Our extensive seasonality controls will capture the secular effect of weather patterns and elections on the timing of hartals.

${ }^{21}$ We cluster our standard errors at the day level, which is the level at which our dependent variables of interest are measured. As we show later in the paper, our standard errors remain largely unchanged if we cluster them at the two-way level (firm and day) instead.
} 
We can use our estimates in column (2) to introduce our method of calculating the cumulative effect of a hartal on export shipments. This approach relies on the following logic. Suppose there is a hartal on day $t$. From our estimates in Table 5, we know that this hartal will have an effect on the probability of making a shipment on day $t$. We also know that this hartal will affect an exporter's probability of making a shipment on the day before. Further, as we show below, this hartal will also affect an exporter's probability of making a shipment on the days immediately after. Thus, the sum of these three effects represents the cumulative effect of a hartal. More precisely, the cumulative effect is given by $\sum_{s=-1}^{6} \beta_{t-s}$. This cumulative effect is reported at the bottom of column (2). For the twoday event window examined here, the cumulative effect is a 0.50 percentage point reduction in the probability of making an export shipment.

In columns (3) to (4) of Table 5 we extend our event window sequentially by two days at a time. For instance, in column (3) we include the lagged hartal indicators $H_{t-1}$ and $H_{t-2}$ while in column (4) we add the lagged hartal indicators $H_{t-3}$ and $H_{t-4}$. The coefficients on these additional lagged indicators are both relatively small in magnitude and statistically insignificant. In both cases, the cumulative effect is a 0.20 percentage point reduction in the probability of making an export shipment.

Finally, in column (5) we extend our event window to eight days by including the lagged hartal indicators $H_{t-5}$ and $H_{t-6}$. As above, the coefficients on these lagged indicators are both relatively small in magnitude and statistically insignificant. However, the cumulative effect of a hartal during this eight-day event window is a 0.02 percentage point increase in the probability of making an export shipment. Importantly, this result suggests that the cumulative effect of hartal approaches zero during the eight-day event window. This adjustment behavior is illustrated more clearly in Figure 5, which plots the cumulative effect over the entire eight-day event window. The takeaway message here is that, over an eight-day event window, a hartal does not have a cumulative effect of the probability of making an export shipment. This is because the average exporter in our sample compensates for the reduced probability of making an export shipment on the day of the hartal by increasing the probability of making a shipment the before a hartal as well as the days after.

To demonstrate that our core result is not sensitive to restricting the event window to eight days, we extend our event window further in column (6). In particular, we add two additional lead indicators, $H_{t+2}$ and $H_{t+3}$, as well as two additional lagged indicators $H_{t-7}$ and $H_{t-8}$. As the results 
demonstrate, the coefficients of these additional hartal indicators are both small in magnitude and statistically insignificant. ${ }^{22}$ Further, the cumulative effect over this 12-day event window is also statistically insignificant. Thus, extending our default event window in this manner does not change our key takeaway message.

\subsection{Calculating the Added Cost of Hartals}

Our results thus far suggest that hartals cause only a minor disruption to export shipments. In particular, we find that while there is a small decrease in the probability of making a shipment on the day of the hartal itself, there is an increase in this probability the day before the hartal and no cumulative effect over an eight-day event window. In this section, we calculate an additional cost of hartals, which is the increase in the fixed cost of transporting goods to the port. Continuing to export during a hartal is likely to be costly for at least three reasons. First, exporters typically have to pay higher prices to transport companies during a hartal. Second, there is a probability that hartal activists may vandalize transport vehicles or set them on fire. In such an event, an exporter's shipment may be completely destroyed. Lastly, to the extent that exporters invest in added security for their shipments on hartal days, the cost of transport on these days will also increase.

In this section we use a simple conceptual framework to estimate the added cost of exporting during a hartal. Consider an exporter $i$ that enters into an agreement with a foreign buyer. The agreement stipulates the quantity of a product that the exporter must produce, the price of each unit, and the date $T$ on which the shipment is to be made. The price and quantity of goods to be shipped are determined by the buyer and are typically non-negotiable. As a result, we assume that the exporter takes the total f.o.b. value of the shipment as given. Let this value be $V_{i}$. In contrast, we assume that the exporter can deviate from the agreed shipment date depending on whether or not there is a hartal on day $T$.

\footnotetext{
${ }^{22}$ Note that the median notice period provided for a hartal is three days in our sample period of 2010 to 2013. Our informal discussions with garments exporters reveal that the transportation segment is typically 1 to 2 days and includes transportation related logistic preparations. Therefore, a hartal that occurred at day $T$ was typically announced during the final few days of an exporter's production segment. These last few days of the production segment involves sorting and packaging of goods, third party inspection, as well as the buyer's own inspection. Most importantly, the schedule for each production line in a factory gets tighter as its moves closer to its completion date. Therefore, the typical exporter has very little scope to bring forward its shipment date by more than one day.
} 
When deciding whether or not to export during a hartal, an exporter must weigh the added costs of doing so with the cost of missing the agreed shipment date. Suppose that the cost of transporting a shipment to the port on a non-hartal day is $f V_{i}$, where $0 \leq f \leq 1$ is the cost of transporting a shipment worth one Taka. Then the cost of transporting the same shipment to the port on a hartal day will be $\gamma f V_{i}$, where $\gamma>1$ is the transportation cost premium due to a hartal. In contrast, the cost of not exporting on a hartal day is the penalty, $\varphi_{i}$, per Taka of shipment that an exporter incurs for missing its agreed shipment date, where $0 \leq \varphi_{i} \leq 1$. Here $\varphi_{i}$ need not represent a monetary transfer, but could capture the adverse (monetized) effect of missing a shipment date on the probability of receiving a future order. Given this setup, when deciding whether or not to export on a hartal day, the exporter will seek to maximize the following

$$
\left(1-\varphi_{i} d\right) V_{i}-[1+(1-d) \gamma] f V_{i}
$$

where $d \in\{0,1\}$ is an indicator variable for whether or not a shipment is delayed. That is, $d$ is equal to zero if the firm chooses to export on the day of a hartal and is one otherwise. By comparing (2) at both values of $d$, we can conclude that an exporter will choose to export on a hartal day if and only if

$$
\varphi_{i} \geq \gamma f
$$

That is, a firm will export during a hartal if the penalty for missing the agreed shipment date is greater than or equal to the added cost of shipping on the hartal day. Now consider a firm with a value of $\varphi_{i}$ such that the following holds

$$
\gamma=\frac{\varphi_{i}}{f}
$$

Equation (4) tells us the value of $\gamma$ at which the cut-off firm is indifferent between exporting and not exporting during a hartal. That is, it separates the firms that choose to export during a hartal from those that don't and provides us with a simple way to calculate the transportation cost premium associated with a hartal.

To calculate $\gamma$, we need an estimate for both the penalty, $\varphi_{i}$, and the cost of transporting goods, $f$. To estimate $\varphi$, we rely on the results of Hummels and Schaur (2013). They use productlevel import data to the U.S. over the period 1991 to 2005 to measure the importance of time (or delays) as a barrier to international trade. In particular, they use their data to calculate the advalorem tariff equivalent of each additional day in transit. This tariff equivalent tells us the cost of a 
day's delay, expressed as a fraction of the export value. As a result, it is an appropriate proxy for the penalty, $\varphi_{i}$. In their paper, Hummels and Schaur (2013) suggest that this ad-valorem equivalent takes a value of up to 2.10 percent. If we treat these as proxies for $\varphi_{i}$, it implies that the penalty associated with missing the agreed shipment date represents up to 2.10 percent of the shipment value. ${ }^{23}$

Next, we use data from the 2016 round of the Doing Business Report to calculate $f$. These reports are annual publications of the World Bank that provide information on the institutional and infrastructural constraints faced by firms in the countries that they survey. The 2016 report lists the domestic transport cost for apparel exporters in Bangladesh, which they estimate to be USD 231 (Tk. 18,112). ${ }^{24}$ This is the estimated cost of transporting a standardized shipment between Dhaka and Chittagong Port. As mentioned previously, the majority of garments factories in Bangladesh are located near Dhaka. Thus, the Dhaka to Chittagong Port route is the most common route taken by the exporters in our sample. We divide this figure by the average value of a consignment during our sample period to calculate the transport cost per Taka of shipment. ${ }^{25}$ With these values of $\varphi_{i}$ and $f$, we use (4) to calculate a cost premium of $\gamma=1.69$. This suggests that hartals increase the cost of transporting a consignment by 69 percent.

\subsection{Hartal Type}

Thus far, we have not allowed the effect of hartals to depend on the characteristics of the hartal itself or the characteristics of the exporter. Such heterogeneity is important as we would expect that single-day hartals are much less disruptive to export shipments than multiple-day hartals. Similarly, one would expect larger and more experienced exporters to be better able to adjust their shipments in response to a hartal.

\footnotetext{
${ }^{23}$ Hummels and Schaur (2013) provide a set of estimates that ranges from 0.60 percent to 2.10 percent. We chose the upper bound of these estimates to account for the fact that our framework ignores the cost of arranging transport on an alternate shipment date. In particular, an exporter in our sample is typically given three-day's notice regarding a hartal. If it is to change its shipment date, it must arrange transport on an alternate date on short notice. We ignore this cost in our framework above. Thus, using the upper bound value of $\varphi_{i}$ is important as it allows us to account for this omission.

${ }^{24}$ We convert this value to Bangladeshi Takas using a exchange rate of $1 \mathrm{USD}=\mathrm{Tk} .78 .41$.

${ }^{25}$ The transport cost of 18,112 Takas reported by the Doing Business report is for a 15-tonne consignment. Unfortunately, we do not observe the quantity of goods in each consignment in our sample. Instead, we assume that the average consignment in our sample is 15 tonnes. We then use this to divide the transport cost of 18,112 Taka by the value of the average consignment in our sample to calculate the transport cost per Taka of shipment. This yields a value of $f=0.012$.
} 
To guide our choice of which aspect of hartal and exporter heterogeneity to explore, consider a version of the expression in (3)

$$
\varphi_{i} \geq \gamma_{t} f
$$

where we now allow $\gamma$ to be date specific. Recall that this expression states that an exporter will ship its goods during a hartal if its reputational penalty due to missing a shipment date $\left(\varphi_{i}\right)$ is greater than or equal to the added cost of transporting goods to the port on a hartal day, $\gamma_{t} f$. Equation (5) guides us on what type of hartal and exporter characteristic to consider below. Let us begin with the former. From (5), we know that hartals that disproportionately raise $\gamma_{t}$ will lead to greater reduction in the probability of export shipment on day $t$. To explore whether this is the case, we examine the differential impact of single-day and multiple-day hartals in Table 6 . We begin in column (1) by examining the effect of single-day hartals. We define a single-day hartal as one where there was a hartal on day $T$ and there wasn't a hartal the day before as well as the day after. We then estimated equation (1) with this definition of a hartal. Here, the lagged variable $H_{t-s}$ takes the value of one if there was a single-day hartal on day $t-s$ for $s=-1$ to $s=6$ and no hartal on day $t$.

In our baseline estimation in section 5.1, we compared the export shipment probability of firms in our sample on the day of a hartal with the shipment probability on a seasonally-adjusted nonhartal day. Thus, seasonally-adjusted non-hartal days were our counterfactual. In column (1) of Table 6, the unadjusted counterfactual includes all seasonally-adjusted non-single-hartal days. In other words, without any further restrictions, it includes both non-hartal days as well as hartal days that were part of a series of hartals that spanned more than a single day. As a result, to ensure that our counterfactual is appropriate, we exclude multiple-day hartal days from our sample in column (1). This adjusted counterfactual now only includes non-hartal days, as was the case with the baseline results above. The results in column (1) suggest that, for the average exporter, the likelihood of making a shipment increases on the day before a hartal. However, unlike the earlier results, there is no significant reduction in the probability of making a shipment on the day of the hartal itself. Overall, the results here suggest that single-day hartals are much less disruptive to exporters relative to the baseline in Table 5 .

In column (2) of Table 6 we consider the effect of hartals that spanned between two and four days. To see how these hartal indicators are defined, consider a sequence of hartals that span four days. Here, $H_{t}$ takes the value of one on the first day of the hartal sequence, $H_{t-1}$ takes the value of 
one on the second day of the hartal sequence, $H_{t-2}$ takes the value of one on the third day of the hartal sequence, and $H_{t-3}$ takes the value of one on the fourth day of the hartal sequence. We define our hartal indicators in a similar manner in the case of two and three-day hartals. ${ }^{26}$ Since the hartal period now spans up to four days, we extend our baseline event window by four additional days as well. In particular, we now define our hartal indicators, $H_{t-s}$, for $s=-3$ to $s=8$. The results suggest that, for the average exporter, the probability of making an export shipment drops significantly on the second day of the hartal sequence. In particular, we find that a hartal on this day lowers the probability of making a shipment by 3 percentage points. While there is a reduction in the probability of making an export shipment on the first, third, and fourth days of the hartal sequence, these effects are both relatively small in magnitude and also statistically insignificant. Interestingly, we find that the cumulative effect over this twelve-day event window is a 5.10 percentage point reduction in the probability of making an export shipment. This suggests that these multiple-day hartals are much more disruptive to exporters in the sense that it does not allow them to fully reallocate the reduced shipments as a result of the hartals.

In column (3) we examine whether hartals that occurred during the period that preceded the nationwide elections of $5^{\text {th }}$ January, 2014 had different effects on export behavior. To explore this, we restrict the sample to the period between July and December, 2013. Of the 99 hartals that took place between 2010 and 2013, 40 occurred during this six-month period. As a result, the hartals during this period were announced with greater frequency and shorter notice to exporters and are likely to be more disruptive. The results in column (3) of Table 6 suggest that despite the greater frequency of hartals during this period, exporters exhibited similar adjustment behavior to the baseline. That is, hartals lowered the probability of making a shipment on the day of the hartal itself, but did not have a statistically significant cumulative effect over the event window. The main difference between these results and the baseline is the larger decrease in the probability of making a shipment during a hartal and the fact that shipments were reallocated to the day after the hartal rather than the day before.

Next, we examine the differential effect of hartals that were announced with short notice versus hartals that were announced with long notice. It is likely that a hartal announced with a longer

\footnotetext{
${ }^{26}$ As Table 1 demonstrates, the majority of hartals in our sample period span a single-day and relatively few span two, three, and four days respectively. Thus, if we were to consider two, three, and four-day hartals separately we will be left with hartal indicators with very little variation. To avoid this problem, we group together two, three, and four-day hartals and refer to them as multiple-day hartals.
} 
notice period will give exporters the ability to organize transport on alternate shipment dates in a cost-effective manner. In turn, this will better allow exporters to reallocate their shipments away from hartal days and towards others. To explore this, we define a short-notice hartal as one that was announced with three of fewer days' notice. Three days is the median gap between when a hartal is announced and when it takes place during our sample period of 2010 to 2013. The remaining hartals were classified as having a long notice. In column (4) of Table 6 we examine the effect of short-notice hartals. As before, we want the counterfactual to be the export shipment probability on seasonallyadjusted non-hartal days. As a result, in column (4), we omit from our sample days in which there was a long-notice hartal. The results suggest that the adjustment behavior of the average exporter is similar in the case of a short-notice hartal when compared to the baseline scenario in Table 5.

Next, in column (5) we examine the effect of long-notice hartals. As before, we omit shortnotice hartal days to ensure that our counterfactual is a seasonally-adjusted non- hartal day. Once again, the results indicate that the adjustment behavior of the average exporter is similar in the case of a long-notice hartal when compared to the baseline scenario. However, by comparing the results in columns (4) and (5), we find that the reduction in the probability of making an export shipment on the day of a hartal is greater in the case of a long-notice hartal when compared to a short-notice hartal. This result is consistent with the idea that a longer-notice hartal, by providing an exporter with greater scope to arrange transportation on alternate dates cheaply, will facilitate an exporter's ability to reallocate its shipment dates. In contrast, short-notice hartals are less likely to give the average exporter the time needed to make these alternate arrangements. To the extent that this is the case, exporters will have lesser scope to reallocate their shipment dates in the case of short-notice hartal.

\subsection{Exporter Characteristics}

Equation (5) also suggests that exporter characteristics that determine its reputational penalty will affect its shipment response to a hartal. We explore these exporter characteristics in Table 7 . In columns (1) and (2) we restrict the sample to small and large exporters respectively and re-estimate equation (1). To categorize exporters as small we first calculate each exporter's average daily exports over our sample period. We then classify an exporter as small if its average daily exports are below the sample median. All other exporters are classified as large. The results suggest that a hartal lowers the probability of making a shipment for both small and large exporters. We also find that these exporters compensate for this reduction by being more likely to make a shipment the day before a 
hartal. Interestingly, we find that the magnitude of adjustment made by small firms is significantly smaller. In particular, we find that for small exporters there is 0.42 percentage point reduction in the probability of making an export shipment on the day of the hartal itself and a 0.20 percentage point increase in this probability the day before the hartal. In contrast, for large exporters we observe a 1.90 percentage point reduction in the probability of exporting on the day of a hartal and a 1.20 percentage point increase in the probability of exporting the day before a hartal. This difference is consistent with the idea that larger exporters are better able to renegotiate shipment dates with their buyer and are therefore likely to incur a lower reputational penalty from changing its shipment date. Importantly, the cumulative effect for both types of exporters over the eight-day event window is small in magnitude and statistically insignificant.

Another explanation for the difference in results in columns (1) and (2) is that some exporters, due to their longer export history and/or a longer relationship with its buyers, suffer a smaller reputational penalty from missing its agreed shipment date. Given the higher costs associated with transporting on the day of a hartal, these firms may optimally choose to reallocate their shipment to other days. To examine whether this is the case, we now explore whether a firm's export history determines its adjustment behavior in response to a hartal. In our data, we only observe each firm's export history during the period 2005 to 2013 and therefore do not know its full export history. Nonetheless, we can distinguish between exporters that first appear in our sample in the later period (inexperienced) and exporters that appear earlier (experienced).

In columns (3) and (4) we restrict the sample to firms that first exported in or after 2010 (inexperienced) and those that first exported before 2010 (experienced) respectively. We chose 2010 as the cut-off as this ensures that the sample sizes in columns (3) and (4) are relatively similar. The results in column (3) suggest that there is a small decrease in the probability of making an export shipment during a hartal for inexperienced exporters. The cumulative effect over the event window is close to zero and statistically insignificant. Thus, these exporters demonstrate very little reallocation of export shipments during the event window. In contrast, in column (4) we observe a 1.80 percentage point reduction in the probability of exporting on the day of a hartal and a 1.70 percentage point increase in the probability of exporting the day before a hartal for experienced exporters. As before, the cumulative effect over the event window is close to zero and statistically insignificant. 
The results in the first four columns in Table 7 suggest that some exporters are better able to lower their exposure to a hartal by reallocating their shipments across the event window. This is consistent with the idea that these exporters, due to their longer working history with buyers, are better able to renegotiate their shipment dates. However, it can also be the case that some exporters have the flexibility to change their transportation arrangement to minimize their exposure to a hartal. If this is important then we should observe that exporters that ship frequently and therefore are more likely to have transportation arrangements in place that allow them to be flexible, are better able to reallocate their export shipments.

To examine this, we compare the results for infrequent versus frequent shippers in columns (5) and (6). To categorize firms as either frequent or infrequent shippers, we first calculated the average number of annual shipments made by each exporter during our sample period. We then classified an exporter as an infrequent shipper if its average annual number of export shipments were below the sample median. All other exporters were classified as frequent shippers. The results in column (5) suggest that a hartal has no noticeable contemporaneous or cumulative effect on the export shipment of infrequent shippers. In contrast, the results in column (6) suggests that for frequent shippers, there is a 2.39 percentage point reduction in the probability of exporting on the day of a hartal and a 1.46 percentage point increase in the probability of exporting the day before a hartal. As before, the cumulative effect over the event window is close to zero and statistically insignificant.

\subsection{Robustness Checks}

In Table 8, we subject our primary results to a series of robustness checks. Thus far we have assumed that a hartal provides a uniform "treatment" to all exporters in the sample and that an exporter's response to it may be heterogeneous based on their individual characteristics. But it could be the case that an exporter's exposure to a hartal is also heterogeneous. For instance, an exporter that is located close to Chittagong port may have a lower exposure to a hartal compared to an exporter located in Dhaka. In such cases, it is more useful to think of the exposure to a hartal as having both a uniform as well as an exporter-specific component. More precisely, we can rewrite our hartal indicator as $H_{i t}=H_{t}+h_{i}$, where $H_{t}$ is the component of a hartal's treatment that applies uniformly to all exporters while $h_{i}$ is the exporter-specific component that is heterogeneous across exporters. Substituting this new hartal indicator into the baseline econometric specification yields 


$$
\operatorname{Pr}\left[X_{i t}>0\right]=\alpha_{2}+\sum_{s=-1}^{6} \beta_{s} H_{t-s}+\theta_{i}+\theta_{d}^{w}+\theta_{d}^{Y}+\theta_{y}+\vartheta_{i t}
$$

where $\theta_{i}$ are firm fixed effects and controls for any time-invariant ability that an exporter may have to minimize its exposure to a hartal. A second advantage of estimating (6) relative to the baseline is that the inclusion of $\theta_{i}$ allows us to control for any correlation between the timing of hartals and unobservable, time-invariant exporter characteristics. The results from estimating equation (6) are reported in column (1) of Table 8. ${ }^{27}$ As is evident from the table, the key results of the paper remain highly robust to including firm fixed effects. This suggests that neither hartal treatment heterogeneity nor the possible correlation between the timing of hartals and unobserved, time-invariant exporter characteristics is a first-order concern in this application.

Next, in column (2) we estimate a version of equation (1) where we cluster the standard errors at both the firm and day level. Recall that our default approach thus far has been to cluster at the day level alone. As the results in this column confirm, clustering at the two-way level does not change the key results of the paper. In fact, the two-way clustered standard errors are almost identical to the one-way clustered standard errors up to three decimal places.

In column (3) of Table 8 we account for the fact that a firm's shipment date choice may be driven by short-term fluctuations in shipping prices. To examine whether this affects our primary results, we estimate an augmented version of (1) where we include the natural logarithm of the daily Baltic Dry Index (BDI). This index captures the price of shipping a range of primary commodities by sea using dry bulk carriers. It is constructed by the London Baltic Exchange based on daily information from a panel of shipbrokers. We use this as a proxy for short-term changes in the cost of shipping internationally. As the results in column (3) suggest, adding the BDI to the baseline specification does not significantly alter the key results of the paper. In particular, we still find a decrease in the probability of making a shipment on the day of a hartal and an increase on the day before. We also find that the BDI has a negative and statistically significant effect on the probability of exporting. This suggests that a higher BDI (i.e. higher average freight charges) lowers the probability that a firm will export on any given day. Note that the BDI data are not available for all days in our sample. Hence the sample size in column (3) is lower than the baseline.

\footnotetext{
${ }^{27}$ Due to the large sample size and the presence of two high-dimensional fixed effects (firm and day-of-year), we estimate (4) using the STATA command reg2hdfe. This command implements the procedure described in Guimaraes and Portugal (2010). With large sample sizes, this procedure imposes a much lower computational and memory burden relative to a standard within estimator.
} 
A limitation of the BDI data is that it only captures freight charges and not necessarily fuel costs. To account for the latter, we add the natural logarithm of the daily crude oil price in addition to the BDI in column (4) of Table 8. The crude oil price data are from the Federal Reserve Bank of St Louis and capture the daily spot price in U.S. dollars of a barrel of crude oil. As before, the daily crude oil price is not available for all days in our sample, which is why the sample size in column (4) is smaller than column (3). Nonetheless, it is the case that adding the daily crude oil price also does not change the key results of the paper.

Lastly, we examine whether our key results are robust to alternate methods of controlling for seasonal trends in our data. Up to this point we have controlled for seasonal trends using a combination of day-of-year fixed effects, day-of-week fixed effects, and year fixed effects. To examine whether our results are robust to alternate methods of controlling for seasonality trends, we replace the day-of-year fixed effects with month fixed effects and an indicator for public holidays in Bangladesh. The results from this regression are reported in column (5) of Table 8. As these estimates clearly demonstrate, our key results go through when we use this alternate method of controlling for seasonality trends.

\section{The Effect of Hartals on Export Value and Mode}

Our analysis thus far has focused on the effect of hartals on an exporter's choice of shipment date. In other words, we have examined whether a hartal affects a firm's export decision at the extensive margin. In Table 9 we examine whether hartals affect a firm's export decision at the intensive margin. That is, we now ask whether a hartal alters the value of the goods that a firm exports on any given day. In column (1) we restrict the sample to observations with positive exports and then estimate a version of equation (1) with the natural logarithm of a firm's daily exports as the dependent variable. The sign of the coefficient of the hartal indicator, $H_{t}$, is negative and large in magnitude.

A possible limitation of the results in column (1) is that it does not account for day-to-day changes in the composition of the sample. This means that the negative coefficient of the $H_{t}$ variable in column (1) could reflect a true intensive margin reduction or it could reflect the fact that larger firms disproportionately lower their probability of exporting on the day of a hartal. To account for this, we introduce firm fixed effects in column (2). These fixed effects will control for time-invariant 
firm characteristics such as size, export history etc. and will allow us to account for day-to-day compositional changes in the sample.

The coefficient of the hartal indicator, $H_{t}$, in column (2) remains negative, but is now statistically significant. In addition, we observe an increase in the value of exports the day after the hartal itself. The magnitude of this adjustment is very similar to the size of the reduction in export value on the day of the hartal. Interestingly, in both the OLS regression in column (1) and the fixedeffects regression in column (2), we find that the cumulative effect of a hartal on the intensive margin over the eight-day event window is positive and statistically significant. When combined with our finding in Table 5 that the cumulative effect of a hartal on the probability of making an export shipment is close to zero, we can conclude that a hartal does not reduce the cumulative value of a firm's exports over our event window.

Next, we examine whether a hartal affects an exporter's choice of transport mode. That is, we ask whether the exporters in our sample are more likely to use air transport to make up for the disruption caused by a hartal. Given that air transport is significantly more expensive (Hummels and Schaur, 2013), to the extent that hartals lead to greater use of such transport, it can have an adverse effect on the profit margin of garments exporters. To examine whether this is the case, we first estimate a version of our baseline econometric specification in (1) where the dependent variable is now an indicator that takes the value of one if an exporter using air transport on any given day and is zero otherwise. In column (3) we report the results based on an OLS estimation of this new specification while in column (4) we report the results after including firm fixed effects.

The results in both columns suggest that the coefficient of the hartal indicator, $H_{t}$, is positive, statistically significant, and large in magnitude. This suggests that the average exporter in the sample does increasingly use air transport on the day of a hartal. Interestingly, we find that these exporters compensate for the higher costs associated with this increased use of air transport by lowering the use of air shipment on other days in the event window. In particular, we find that the coefficient for $H_{t-5}$ is negative and statistically significant. Further, we also find that the cumulative effect of a hartal on the decision to use air transport over the entire event window is small in magnitude and statistically insignificant. Thus, the results in columns (3) and (4) of Table 9 indicate that while hartals do cause exporters to increasingly switch to expensive air transport, these exporters are able to attenuate the effects of this on their profitability by lowering their use of air transport on subsequent shipments. 


\section{Conclusion}

In this paper we examined the impact of political strikes, locally known as hartals, on the behavior of garments exporters in Bangladesh. In particular, we examined whether these hartals affected the timing of export shipments, the size (in value) of shipments, and the use of air transport. To do so, we used data on all hartals during the years 2010 to 2013. In particular, we collect the date of a hartal, when it was announced, why it was announced, and whether it spanned a single day or multiple days. We pair these data with the universe of export transactions that occurred during our sample period. These data, which were collected by the National Board of Revenue, allows us to construct a working sample consisting of a daily panel of 8,161 exporters over 1,453 days.

These high-frequency data allowed us to identify whether an exporter adjusted its shipment date, shipment size, and transport mode during a short event window around each hartal. To the extent that the adjustment behavior we observe is expensive, our analysis allowed us to identify an additional cost of political violence that has been under-studied in the literature. A second advantage of our setting is that we were able to isolate a single channel through which political violence affects exporters. Unlike other forms of political violence, hartals are targeted towards disrupting Bangladesh's transport network. There is no damage to utility infrastructure or factories during a hartal. Further, since the mainly female workers in the garments industry live close to their factories, hartals do not cause worker absenteeism or other forms of production disruptions (Ashraf et al., 2105). As a result, hartals provide an unusually clean shock to Bangladesh's transport network that allowed us to isolate how such violence affects exporters through a single channel.

We found that hartals lowered the probability that a firm in our sample will export on that day by 1.20 percentage points. However, we also found that there was no cumulative effect of a hartal on the probability of making an export shipment over our eight-day event window. That is, the exporters in our sample were resilient enough to reallocate their shipment dates to ensure that there was no overall reduction in shipments as a result of a hartal. While this result held for hartals that spanned a single say, we also found that during hartals that spanned between two to four days, there was a cumulative reduction in the probability of making an export shipment. Having established that the typical hartal does not significantly disrupt export shipments, we then calculated the impact of hartals on the cost of transporting goods to the port. Our calculations suggest that this cost increases by 69 percent due to a hartal. We then examined whether these effects varied according to exporter 
characteristics. Here we found that regardless of size, export history, and frequency of shipments, all exporters use the adjustment behavior that we identified in our baseline results. Lastly, we also found that hartals due to decrease the value of exports and does not have a cumulative effect on the probability of using air transport, even though it does increase the likelihood of using air transport on the day of the hartal itself.

Our results provide important insights on how policy makers in other developing countries can shield their firms from the adverse effects of political violence. Because we are able to isolate the effect of political violence through the transportation channel alone, we can conclude that the transport disruptions caused by such violence do not have a first-order effect on the shipment behavior of exporters. These exporters are sufficiently resilient that they use costly adjustment behavior to minimize the adverse effects of hartals. The key feature of hartals that allows this to happen is that it does not disrupt an exporter's production and only disrupts its transportation. This suggests that preventing political violence from disrupting production may be an important way in which to attenuate its adverse effects on firms.

\section{References}

Abadie, A., Gardeazabal, J., 2003. "The Economic Costs of Conflict: A Case Study of the Basque Country." American Economic Review, 93(1): 113-132.

Ahmed, I., Mortoza, G., 2005. "The Anatomy of Hartal: How to Stage a Hartal," in Beyond Hartal: Toward Democratic Dialogue in Bangladesh. Dhaka: United Nations Development Programme.

Ashraf, A., Machiavello, R., Rabbani, A., Woodruff, C., 2015. "The Effect of Political and Labour Unrest on Productivity: Evidence from Bangladeshi Garments." Mimeograph.

Alesina, A., Özler, S., Roubini, N., Swagel, P., 1996. "Political Instability and Economic Growth." Journal of Economic Growth, 1(2): 189-211.

Barbieri, K., Reuveny, R., 2005. “Economic Globalization and Civil War.” The Journal of Politics, 67(4): $1228-1247$.

Besedes, T., Murshid, A., 2015. "Experimenting with Ash: The Trade Effects of Airspace Closures in the Aftermath of Eyjafjallajkull." Mimeograph.

Birtwistle, G., Siddiqui, N., Fiorito, S., 2013. "Quick Response: Perceptions of UK Fashion Retailers.” International Journal of Retail \& Distribution Management, 31(2): 118-128.

Blattman, C., Miguel, E., 2010. “Civil War.” Journal of Economic Literature, 48(1): 3-57. 
Blomberg, S., Hess, G., 2006. "How Much Does Violence Tax Trade? The Review of Economics and Statistics, 88(4): 599-612.

Chaturvedi, A, 2005. “Rigging Elections with Violence.” Public Choice, 125(1): 189-202.

Collier, P., Duponchel, M., 2012. "The Economic Legacy of Civil War: Firm-Level Evidence from Sierra Leone." Journal of Conflict Resolution, 57(1): 65-88.

Collier, P., Vicente, P., 2012. "Violence, Bribery, and Fraud: The Political Economy of Elections in SubSaharan Africa." Public Choice, 153(1): 117-147.

Daily Star, 2013a. “National Public Perception Study: A Special Supplement.” November 2.

Daily Star, 2013b. “One Shutdown Means Tk. 1,600 cr Losses.” April 4.

Djankov, S., Freund, C., Pham, C., 2010. "Trading on Time." The Review of Economics and Statistics, 92(1): 166-173.

Eaton, J., Kortum, S., Kramarz, F., 2011. “An Anatomy of International Trade: Evidence from French Firms." Econometrica, 79(5): 1453-1498.

Ellman, M., Wantchekon, L., 2000. "Electoral Competition under the Threat of Political Unrest." The Quarterly Journal of Economics, 115(2): 499-531.

Ferdows, K., Lewis, M., Machuca, J., 2004. “Rapid-Fire Fulfillment.” Harvard Business Review, 82(11): $104-117$.

Fernandes, A., 2008 "Firm-Level Productivity in Bangladesh Manufacturing Industries." World Development, 36(10): 1725-1744.

Glick, R., Taylor, A., 2010. "Collateral Damage: Trade Disruption and the Economic Impact of War." The Review of Economics and Statistics, 92(1): 102-127.

Guidolin, M., La Ferrara, E., 2007. “Diamonds Are Forever, Wars are Not: Is Conflict Bad for Private Firms?" American Economic Review, 97(5): 1978-1993.

Guimaraes, P., Portugal, P., 2010. "A Simple Feasible Procedure to Fit Models with High-Dimensional Fixed Effects." The Stata Journal, 10(4): 628-649.

Haroon, J., 2012. “Hartal Halts 4,000 Containers Daily at Ctg Port.” The Financial Express, April 30.

Heath, R., Mobarak, A.M., 2015. "Manufacturing Growth and the Lives of Bangladeshi Women." Journal of Development Economics, 115: 1-15.

Human Rights Watch, 2014. Democracy in the Crossfire. 
Hummels, D., Schaur, G., 2013. “Time as a Trade Barrier." American Economic Review, 103(7): 2935-2959.

Khundker, N., 2005. "The Price of Hartals: Impact on the Economy," in Beyond Hartal: Toward Democratic Dialogue in Bangladesh. Dhaka: United Nations Development Programme.

Ksoll, C., Machiavello, R., Morjaria, A., 2014. “Guns and Roses: Flower Exports and Electoral Violence in Kenya." Mimeograph.

Machiavello, R., Morjaria, A., 2015. "The Value of Relationships: Evidence from a Supply Shock to Kenyan Rose Exports." American Economic Review, 105(9): 2911-2945.

Martin, P., Mayer, T., and Thoenig, M., 2008. "Civil Wars and International Trade." Journal of the European Economic Association, 6(2-3): 541-550.

McKinsey, 2011. Bangladesh's Ready-Made Garments Landscape: The Challenge of Growth.

Nitsch, V., Schumacher, D., 2004. “Terrorism and International Trade: An Empirical Investigation." European Journal of Political Economy, 20(2): 423-433.

Quddus, M, Rashid, S., 2000. Entrepreneurs and Economic Development: The Remarkable Sotry of Garment Exports from Bangladesh. Dhaka: University Press Limited.

Shonchoy, A.S., Tsubota, K., 2015. “Economic Impact of Political Protests (Strikes) on Manufacturing Firms: Evidence from Bangladesh." IDE Discussion Paper No. 523.

Sobhan, R., 2004a. "Structural Dimensions of Malgovernance in Bangladesh." Economic and Political Weekly, 39(36): 4101-4108.

Sobhan, Z., 2004b. "The Mathematics of Hartals." The Daily Star, March 24.

Strauss, S., Taylor, C., 2009. "Democratization and Electoral Violence in Sub-Saharan Africa." Mimeograph.

Suykens, B., Islam, A., 2013. "Hartal as a Complex Political Performance: General Strikes and the Organisation of (Local) Power in Bangladesh." Contributions to Indian Sociology, 47(1): 61-83.

Taplin, I., 2014. "Global Commodity Chains and Fast Fashion: How the Apparel Industry Continues to Re-Invent Itself." Competition and Change, 18(3): 246-264.

Volpe Marincus, C., Blyde, J., 2013. "Shaky Roads and Trembling Exports: Assessing the Trade Effects of Domestic Infrastructure Using a Natural Experiment." Journal of International Economics, 90(1): $148-161$. 


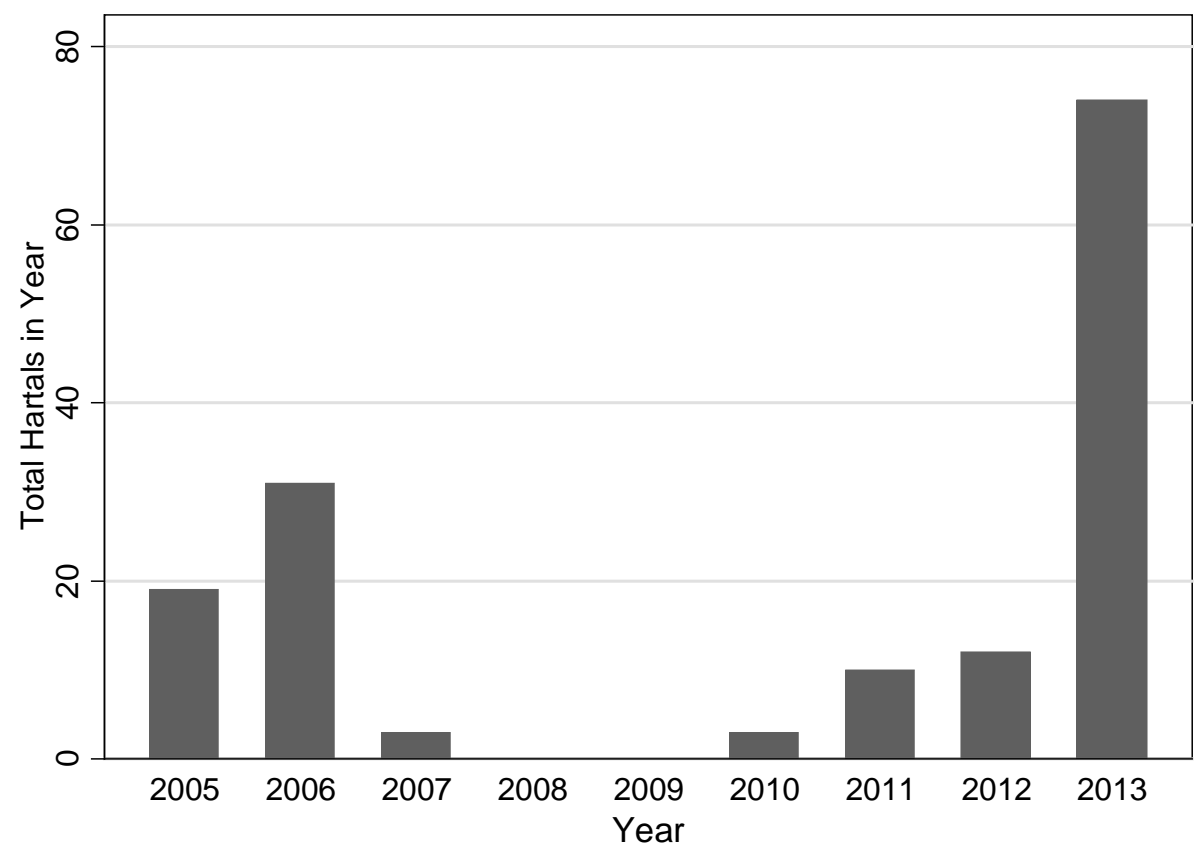

Figure 1: Annual trend in hartals.

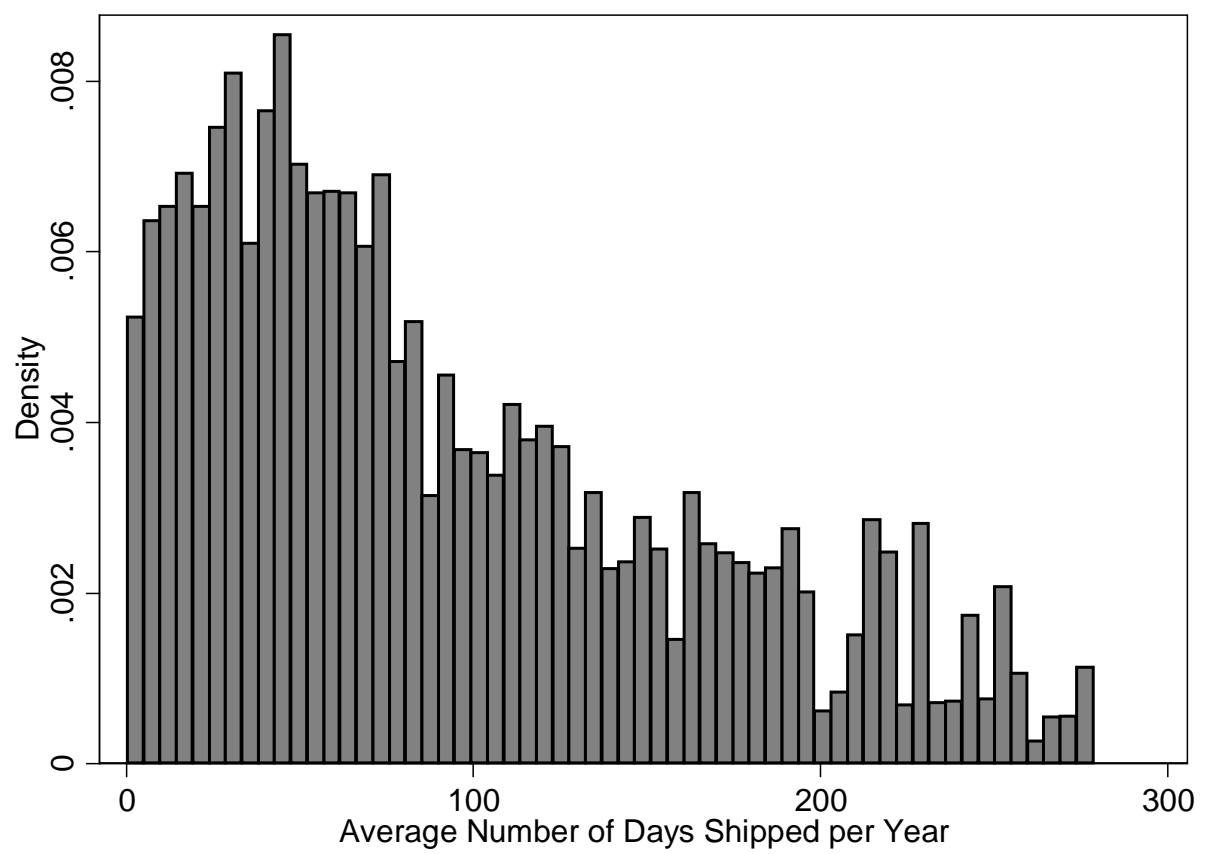

Figure 2: The average number of days shipped per year. 


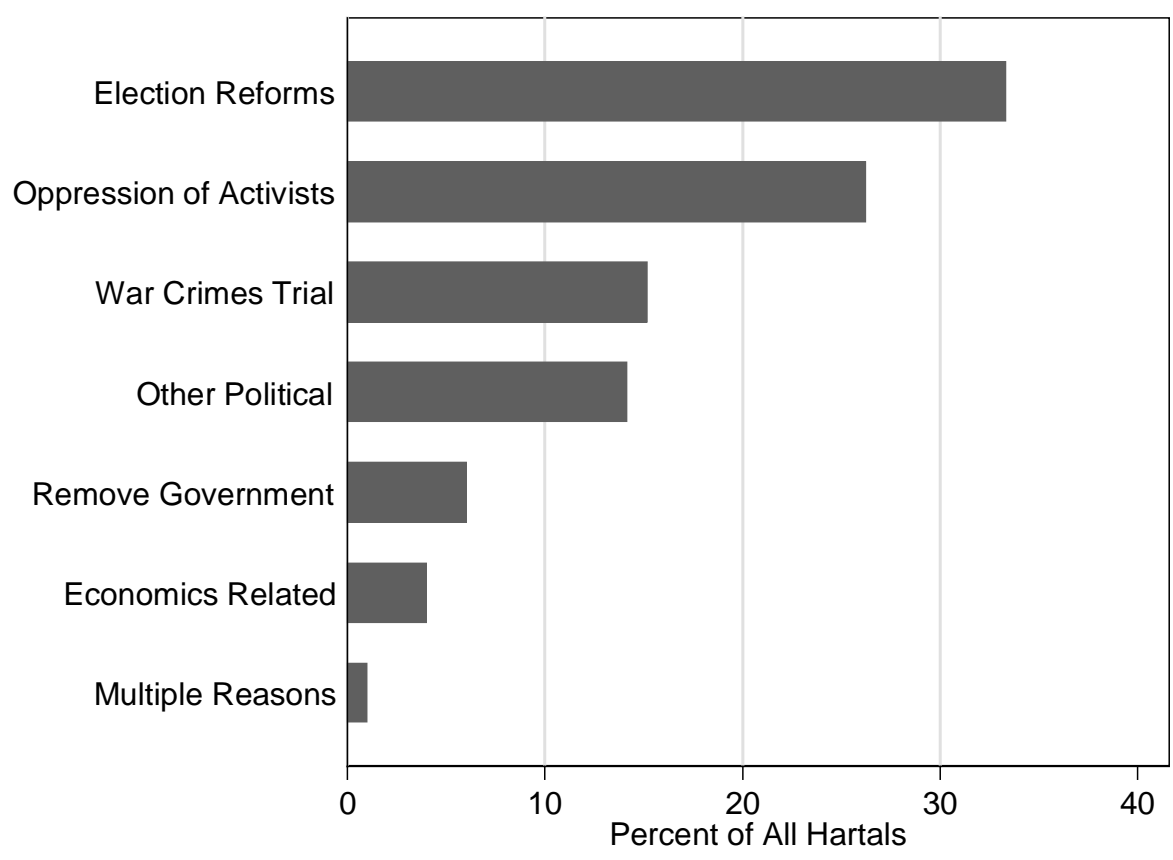

Figure 3: The stated reasons for calling a hartal (2010 to 2013).

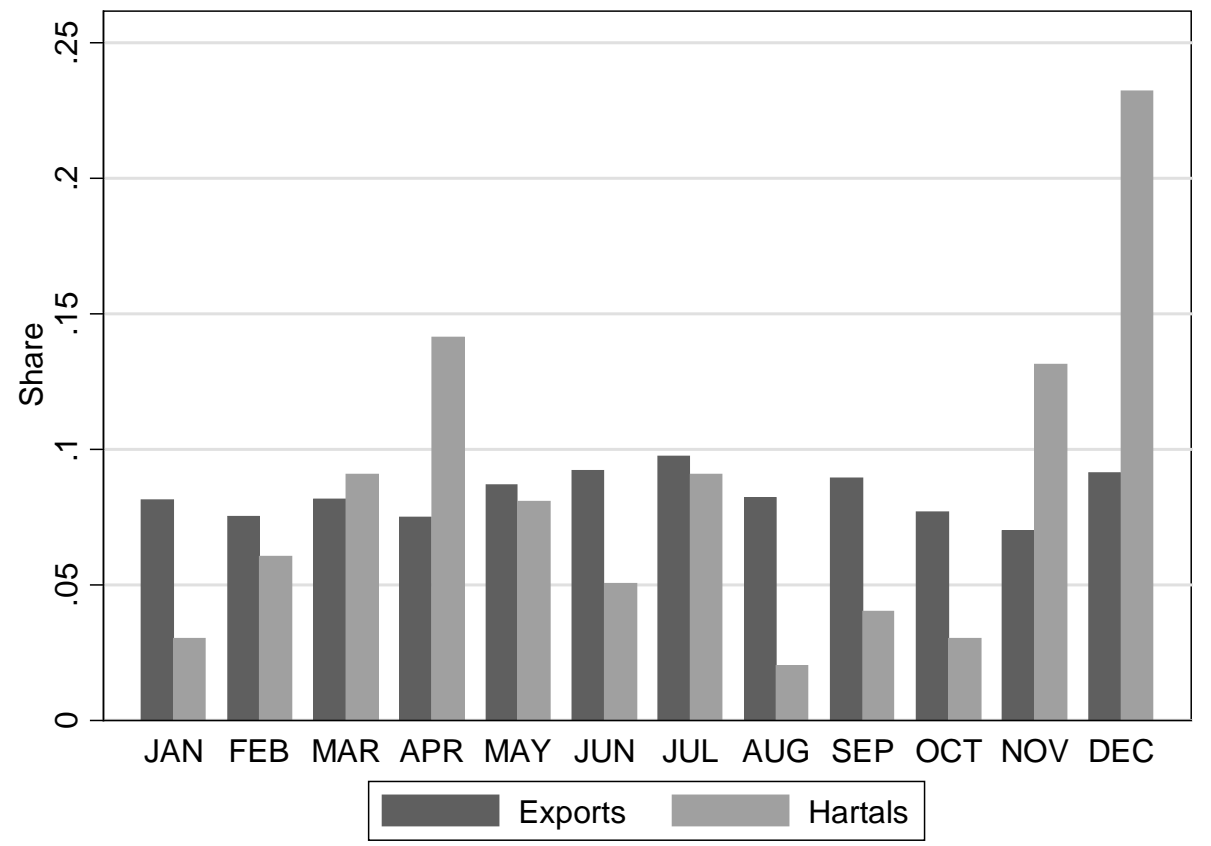

Figure 4: Distribution of hartals and daily exports by month. The correlation coefficient between these two variables is 0.05 . 


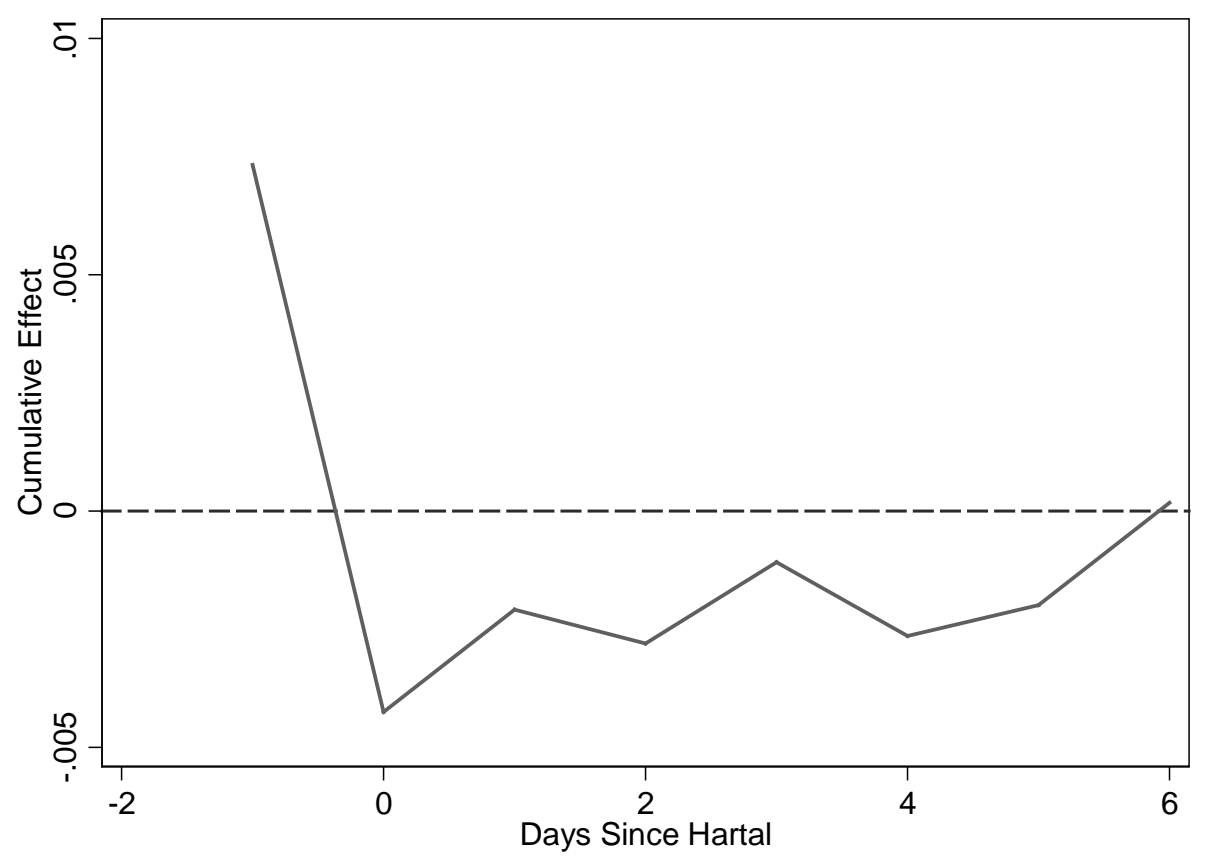

Figure 5: Cumulative effect of a hartal on the probability of exporting. A zero on the horizontal axis represents the day of the hartal. 


\begin{tabular}{|c|c|c|c|}
\hline & $(1)$ & $(2)$ & $(3)$ \\
\hline Years Included & $\begin{array}{c}2005- \\
2013\end{array}$ & $\begin{array}{c}2005- \\
2009\end{array}$ & $\begin{array}{r}2010- \\
2013 \\
\end{array}$ \\
\hline Total Hartals & 152 & 53 & 99 \\
\hline \multicolumn{4}{|l|}{ Fraction of Hartals that spanned: } \\
\hline Single Day & 0.65 & 0.72 & 0.60 \\
\hline Two Day & 0.18 & 0.14 & 0.21 \\
\hline Greater than Two Days & 0.17 & 0.14 & 0.19 \\
\hline Length of Hartals (in hours) & 15.60 & 14.60 & 16.13 \\
\hline Notice Provided (in days) & 5.55 & 7.28 & 4.62 \\
\hline Number of Deaths & 1.49 & 0.52 & 2.01 \\
\hline Number of Injuries & 112.68 & 132.92 & 101.84 \\
\hline
\end{tabular}

Notes: the reported numbers are authors' calculations using data collected from two leading Bangladeshi newspapers: The Daily Star and the Ittefaq. 
Table 2: Validation of the Customs Exports Data

\begin{tabular}{cccc}
\hline & $(1)$ & $(2)$ & $(3)$ \\
\hline & & & \\
Year & World Bank & Customs & $\begin{array}{c}\text { Customs/ } \\
\text { World Bank }\end{array}$ \\
\hline & & & \\
2005 & 577,769 & 571,766 & 1.011 \\
2006 & 914,655 & 792,638 & 1.154 \\
2007 & 631,699 & 860,018 & 0.735 \\
2008 & $1,050,898$ & $1,054,508$ & 0.997 \\
2009 & $1,059,283$ & $1,037,734$ & 1.021 \\
2010 & $1,340,978$ & $1,327,932$ & 1.010 \\
2011 & $1,803,050$ & $1,739,932$ & 1.036 \\
2012 & $2,168,282$ & $1,988,230$ & 1.091 \\
2013 & $2,212,223$ & $2,327,139$ & 0.951 \\
& & & \\
\hline Total & $11,758,837$ & $11,699,897$ & 0.995 \\
\hline
\end{tabular}

Notes: In columns (1) we report the aggregate annual exports for Bangladesh as reported by the World Bank. These are based on balance of payments calculations. In column (2) we report the aggregate annual export data based on our customs data. The correlation coefficient between the two is 0.98 . In column (3) we report the ratio of the World Bank aggregate to the customs aggregate. The monetary values are in millions of Bangladeshi Takas. One US dollar was approximately equivalent to 61.5 Takas in 2005. 
Table 3: Descriptive Statistics of Exports Data

Mean

Median

Total Number of Exporters

8,161

Exporters per Day

623.57

624.00

[148.97]

Daily Firm Exports

4.55

2.31

[7.28]

Number of HS6 Products

5.41

4.00

per Firm per Year

[5.03]

Number of Destinations

5.40

4.00

per Firm per Year

[6.20]

Number of Firm Shipment

92.75

73.00

Days per Year

[69.12]

Fraction of Shipments Made

0.22

Using Air Transport

Notes: In column (1) we report the mean of each variable along with its standard deviation in brackets. All monetary values are in millions of constant 2005 Bangladeshi Takas. One US dollar was approximately equivalent to 61.5 Takas in 2005. 
Table 4: Top Exports Products and Destinations (2010 to 2013)

(1)

Share of

Exports

Panel A: Products

Cotton T-Shirts and Singlets

0.318

Men's or Boys Trousers

Sweaters of Other Textiles

0.088

Women's or Girls Trousers

0.059

Men's or Boys Cotton Shirts

0.055

Panel B: Destinations

United States

Germany

0.250

United Kingdom

France

0.071

Spain

Notes: the share of exports is calculated by dividing the average annual exports for each product or destination by the total average annual exports during the period 2010 to 2013. A product is defined at the six-digit HS level. 
Table 5: The Impact of Hartals on The Probability of Exporting

\begin{tabular}{|c|c|c|c|c|c|c|}
\hline & (1) & (2) & (3) & (4) & (5) & (6) \\
\hline Dependent Variable & \multicolumn{6}{|c|}{ Indicator for Exporter } \\
\hline $\mathrm{H}_{\mathrm{t}}$ & $\begin{array}{c}-0.013^{* * *} \\
(0.002)\end{array}$ & $\begin{array}{c}-0.012^{* * *} \\
(0.002)\end{array}$ & $\begin{array}{c}-0.012^{* * *} \\
(0.002)\end{array}$ & $\begin{array}{c}-0.012^{* * *} \\
(0.002)\end{array}$ & $\begin{array}{c}-0.012^{* * *} \\
(0.002)\end{array}$ & $\begin{array}{c}-0.012^{* * *} \\
(0.002)\end{array}$ \\
\hline $\mathrm{H}_{\mathrm{t}+1}$ & & $\begin{array}{c}0.008^{* * *} \\
(0.002)\end{array}$ & $\begin{array}{c}0.007^{* * *} \\
(0.002)\end{array}$ & $\begin{array}{c}0.008^{* * *} \\
(0.002)\end{array}$ & $\begin{array}{c}0.007^{* * *} \\
(0.002)\end{array}$ & $\begin{array}{c}0.008^{* * *} \\
(0.002)\end{array}$ \\
\hline $\mathrm{H}_{\mathrm{t}-1}$ & & & $\begin{array}{c}0.002 \\
(0.002)\end{array}$ & $\begin{array}{c}0.002 \\
(0.002)\end{array}$ & $\begin{array}{c}0.002 \\
(0.002)\end{array}$ & $\begin{array}{c}0.002 \\
(0.002)\end{array}$ \\
\hline $\mathrm{H}_{\mathrm{t}-2}$ & & & $\begin{array}{l}-0.0003 \\
(0.002)\end{array}$ & $\begin{array}{l}-0.001 \\
(0.003)\end{array}$ & $\begin{array}{l}-0.001 \\
(0.002)\end{array}$ & $\begin{array}{l}-0.001 \\
(0.002)\end{array}$ \\
\hline $\mathrm{H}_{\mathrm{t}-3}$ & & & & $\begin{array}{c}0.002 \\
(0.002)\end{array}$ & $\begin{array}{c}0.002 \\
(0.002)\end{array}$ & $\begin{array}{c}0.002 \\
(0.002)\end{array}$ \\
\hline $\mathrm{H}_{\mathrm{t}-4}$ & & & & $\begin{array}{l}-0.001 \\
(0.002)\end{array}$ & $\begin{array}{l}-0.002 \\
(0.002)\end{array}$ & $\begin{array}{l}-0.001 \\
(0.002)\end{array}$ \\
\hline $\mathrm{H}_{\mathrm{t}-5}$ & & & & & $\begin{array}{c}0.001 \\
(0.002)\end{array}$ & $\begin{array}{c}0.001 \\
(0.002)\end{array}$ \\
\hline $\mathrm{H}_{\mathrm{t}-6}$ & & & & & $\begin{array}{c}0.002 \\
(0.002)\end{array}$ & $\begin{array}{c}0.003 \\
(0.002)\end{array}$ \\
\hline $\mathrm{H}_{\mathrm{t}-7}$ & & & & & & $\begin{array}{l}-0.001 \\
(0.002)\end{array}$ \\
\hline $\mathrm{H}_{\mathrm{t}-8}$ & & & & & & $\begin{array}{l}-0.003 \\
(0.002)\end{array}$ \\
\hline $\mathrm{H}_{\mathrm{t}+2}$ & & & & & & $\begin{array}{l}-0.001 \\
(0.002)\end{array}$ \\
\hline $\mathrm{H}_{\mathrm{t}+3}$ & & & & & & $\begin{array}{l}0.0001 \\
(0.002)\end{array}$ \\
\hline Cumulative effect $\left(\sum \mathrm{H}_{\mathrm{t}+\mathrm{s}}\right)$ & - & -0.005 & -0.002 & -0.002 & 0.0002 & -0.003 \\
\hline P-value $\left(\mathrm{H}_{0}: \sum \mathrm{H}_{\mathrm{t}+\mathrm{s}}=0\right)$ & - & {$[0.155]$} & {$[0.580]$} & {$[0.677]$} & [0.973] & {$[0.662]$} \\
\hline R-squared & 0.002 & 0.002 & 0.002 & 0.002 & 0.002 & 0.002 \\
\hline
\end{tabular}

Notes: $\mathrm{N}=11,857,933$. The dependent variable in all columns is an indicator for whether a firm exports on a given day. All regressions include day-of-year fixed effects, day-of-week fixed effects, year fixed effects, and a constant that is not reported. Robust standard errors in parentheses are clustered at the day level. ${ }^{* *} \mathrm{p}<$ $0.01,{ }^{* *} \mathrm{p}<0.05,{ }^{*} \mathrm{p}<0.1$ 
Table 6: Hartals and Export Shipments by Hartal Characteristic

\begin{tabular}{|c|c|c|c|c|c|}
\hline & $(1)$ & $(2)$ & (3) & $(4)$ & (5) \\
\hline \multicolumn{2}{|l|}{ Dependent Variable } & \multicolumn{4}{|c|}{ Indicator for Exporter } \\
\hline Type of Hartal & $\begin{array}{l}\text { Single- } \\
\text { Day }\end{array}$ & $\begin{array}{l}\text { Two to } \\
\text { Four Day }\end{array}$ & $\begin{array}{c}\text { Pre- } \\
\text { Election }\end{array}$ & $\begin{array}{l}\text { Short- } \\
\text { Notice }\end{array}$ & $\begin{array}{l}\text { Long- } \\
\text { Notice }\end{array}$ \\
\hline \multirow[t]{2}{*}{$\mathrm{H}_{\mathrm{t}}$} & 0.002 & -0.006 & $-0.021^{* *}$ & $-0.009^{* * *}$ & $-0.018^{* * *}$ \\
\hline & $(0.002)$ & $(0.004)$ & $(0.010)$ & $(0.003)$ & $(0.003)$ \\
\hline \multirow[t]{2}{*}{$\mathrm{H}_{\mathrm{t}+1}$} & $0.009^{* * *}$ & 0.006 & 0.005 & $0.008^{* * *}$ & $0.007^{* * *}$ \\
\hline & $(0.002)$ & $(0.005)$ & $(0.014)$ & $(0.003)$ & $(0.003)$ \\
\hline \multirow[t]{2}{*}{$\mathrm{H}_{\mathrm{t}-1}$} & 0.001 & $-0.030^{* * *}$ & $0.029^{* *}$ & 0.003 & 0.001 \\
\hline & $(0.002)$ & $(0.007)$ & $(0.012)$ & $(0.003)$ & $(0.003)$ \\
\hline \multirow[t]{2}{*}{$\mathrm{H}_{\mathrm{t}-2}$} & -0.000 & -0.005 & -0.007 & -0.001 & -0.0005 \\
\hline & $(0.003)$ & $(0.007)$ & $(0.009)$ & $(0.003)$ & $(0.003)$ \\
\hline \multirow[t]{2}{*}{$\mathrm{H}_{\mathrm{t}-3}$} & 0.001 & -0.001 & 0.003 & -0.0002 & 0.005 \\
\hline & $(0.003)$ & $(0.005)$ & $(0.009)$ & $(0.003)$ & $(0.003)$ \\
\hline \multirow[t]{2}{*}{$\mathrm{H}_{\mathrm{t}-4}$} & -0.002 & -0.0002 & -0.003 & -0.003 & 0.0005 \\
\hline & $(0.003)$ & $(0.005)$ & $(0.010)$ & $(0.003)$ & $(0.003)$ \\
\hline \multirow[t]{2}{*}{$\mathrm{H}_{\mathrm{t}-5}$} & 0.001 & -0.001 & $0.016^{*}$ & -0.002 & 0.006 \\
\hline & $(0.002)$ & $(0.004)$ & $(0.009)$ & $(0.002)$ & $(0.003)$ \\
\hline \multirow[t]{2}{*}{$\mathrm{H}_{\mathrm{t}-6}$} & 0.004 & -0.0004 & -0.002 & 0.003 & 0.002 \\
\hline & $(0.002)$ & $(0.004)$ & $(0.008)$ & $(0.002)$ & $(0.003)$ \\
\hline \multirow[t]{2}{*}{$\mathrm{H}_{\mathrm{t}-7}$} & & 0.003 & & & \\
\hline & & $(0.004)$ & & & \\
\hline \multirow[t]{2}{*}{$\mathrm{H}_{\mathrm{t}-8}$} & & -0.007 & & & \\
\hline & & $(0.005)$ & & & \\
\hline \multirow[t]{2}{*}{$\mathrm{H}_{\mathrm{t}+3}$} & & -0.004 & & & \\
\hline & & $(0.005)$ & & & \\
\hline \multirow[t]{2}{*}{$\mathrm{H}_{\mathrm{t}+2}$} & & -0.006 & & & \\
\hline & & $(0.005)$ & & & \\
\hline Cumulative effect $\left(\sum \mathrm{H}_{\mathrm{t}+\mathrm{s}}\right)$ & $0.016^{* *}$ & $-0.051^{* * *}$ & 0.020 & -0.0002 & 0.003 \\
\hline P-value $\left(\mathrm{H}_{0}: \sum \mathrm{H}_{\mathrm{t}+\mathrm{s}}=0\right)$ & {$[0.037]$} & {$[0.002]$} & {$[0.513]$} & {$[0.982]$} & {$[0.652]$} \\
\hline Observations & $11,311,146$ & $11,205,053$ & 851,605 & $11,572,298$ & $11,335,629$ \\
\hline
\end{tabular}

Notes: A single-day hartal is an episode in which there was a hartal on a given day but there wasn't a hartal on either the preceding or the next day. Two to four-day hartals are episodes in which there was a hartal on two to four consecutive days. Pre-election hartals are hartals that were announced during July to December, 2013. This is the six-month period that preceded the January, 2014 elections. The sample used in column (3) is restricted to this six-month period, which is why the sample size is significantly smaller. Short-notice hartals are those that were announced with three or fewer days' notice. All remaining hartals are classified as long notice. The regressions in columns (1) to (2) and (4) to (5) include day-of-year fixed effects, day-of-week fixed effects, and year fixed effects. The regression in column (3) includes an indicator for public holidays, a week-of-year fixed effects, and day-of-week fixed effects. Robust standard errors in parentheses are clustered at the day level. ${ }^{* *} \mathrm{p}<0.01,{ }^{* *} \mathrm{p}<0.05,{ }^{*} \mathrm{p}<0.1$ 
Table 7: The Role of Exporter Characteristics

\begin{tabular}{|c|c|c|c|c|c|c|}
\hline & $(1)$ & (2) & (3) & $(4)$ & $(5)$ & (6) \\
\hline Dependent Variable & \multicolumn{6}{|c|}{ Indicator for Exporter } \\
\hline Exporter Characteristic & Small & Large & $\begin{array}{c}\text { First } \\
\text { Export In } \\
\text { or After } \\
2010\end{array}$ & $\begin{array}{c}\text { First } \\
\text { Export } \\
\text { Before } \\
2010 \\
\end{array}$ & $\begin{array}{l}\text { Infrequent } \\
\text { Shipper }\end{array}$ & $\begin{array}{c}\text { Frequent } \\
\text { Shipper }\end{array}$ \\
\hline $\mathrm{H}_{\mathrm{t}}$ & $\begin{array}{c}-0.004^{* * *} \\
(0.001)\end{array}$ & $\begin{array}{c}-0.019^{* * *} \\
(0.004)\end{array}$ & $\begin{array}{c}-0.006^{* * *} \\
(0.002)\end{array}$ & $\begin{array}{c}-0.018^{* * *} \\
(0.004)\end{array}$ & $\begin{array}{c}0.001 \\
(0.001)\end{array}$ & $\begin{array}{c}-0.024^{* * *} \\
(0.005)\end{array}$ \\
\hline $\mathrm{H}_{\mathrm{t}+1}$ & $\begin{array}{l}0.002^{*} \\
(0.001)\end{array}$ & $\begin{array}{c}0.012^{* * *} \\
(0.004)\end{array}$ & $\begin{array}{l}-0.001 \\
(0.003)\end{array}$ & $\begin{array}{c}0.017^{* * *} \\
(0.004)\end{array}$ & $\begin{array}{l}0.0001 \\
(0.002)\end{array}$ & $\begin{array}{c}0.015^{* * *} \\
(0.005)\end{array}$ \\
\hline $\mathrm{H}_{\mathrm{t}-1}$ & $\begin{array}{c}0.001 \\
(0.001)\end{array}$ & $\begin{array}{c}0.003 \\
(0.004)\end{array}$ & $\begin{array}{c}0.002 \\
(0.004)\end{array}$ & $\begin{array}{c}0.003 \\
(0.005)\end{array}$ & $\begin{array}{l}0.0001 \\
(0.002)\end{array}$ & $\begin{array}{c}0.004 \\
(0.005)\end{array}$ \\
\hline $\mathrm{H}_{\mathrm{t}-2}$ & $\begin{array}{l}-0.001 \\
(0.001)\end{array}$ & $\begin{array}{l}-0.0004 \\
(0.004)\end{array}$ & $\begin{array}{c}0.000 \\
(0.003)\end{array}$ & $\begin{array}{l}-0.002 \\
(0.005)\end{array}$ & $\begin{array}{r}-0.0001 \\
(0.002)\end{array}$ & $\begin{array}{l}-0.001 \\
(0.005)\end{array}$ \\
\hline $\mathrm{H}_{\mathrm{t}-3}$ & $\begin{array}{l}0.0001 \\
(0.001)\end{array}$ & $\begin{array}{c}0.003 \\
(0.004)\end{array}$ & $\begin{array}{c}0.002 \\
(0.003)\end{array}$ & $\begin{array}{c}0.001 \\
(0.005)\end{array}$ & $\begin{array}{c}0.001 \\
(0.002)\end{array}$ & $\begin{array}{c}0.003 \\
(0.005)\end{array}$ \\
\hline $\mathrm{H}_{\mathrm{t}-4}$ & $\begin{array}{l}0.0001 \\
(0.001)\end{array}$ & $\begin{array}{l}-0.003 \\
(0.004)\end{array}$ & $\begin{array}{l}-0.001 \\
(0.003)\end{array}$ & $\begin{array}{l}-0.002 \\
(0.005)\end{array}$ & $\begin{array}{c}0.001 \\
(0.002)\end{array}$ & $\begin{array}{l}-0.004 \\
(0.005)\end{array}$ \\
\hline $\mathrm{H}_{\mathrm{t}-5}$ & $\begin{array}{l}-0.000 \\
(0.001)\end{array}$ & $\begin{array}{c}0.001 \\
(0.003)\end{array}$ & $\begin{array}{c}0.002 \\
(0.003)\end{array}$ & $\begin{array}{l}-0.0005 \\
(0.004)\end{array}$ & $\begin{array}{c}0.001 \\
(0.002)\end{array}$ & $\begin{array}{l}0.0005 \\
(0.004)\end{array}$ \\
\hline $\mathrm{H}_{\mathrm{t}-6}$ & $\begin{array}{c}0.001 \\
(0.001)\end{array}$ & $\begin{array}{c}0.004 \\
(0.003)\end{array}$ & $\begin{array}{c}0.005 \\
(0.003)\end{array}$ & $\begin{array}{l}-0.001 \\
(0.004)\end{array}$ & $\begin{array}{c}0.002 \\
(0.002)\end{array}$ & $\begin{array}{c}0.002 \\
(0.004)\end{array}$ \\
\hline $\begin{array}{l}\text { Cumulative effect }\left(\sum \mathrm{H}_{\mathrm{t}+\mathrm{s}}\right) \\
\text { P-value }\left(\mathrm{H}_{0}: \sum \mathrm{H}_{\mathrm{t}+\mathrm{s}}=0\right)\end{array}$ & $\begin{array}{c}-0.001 \\
{[0.811]}\end{array}$ & $\begin{array}{c}0.001 \\
{[0.905]}\end{array}$ & $\begin{array}{c}0.003 \\
{[0.759]}\end{array}$ & $\begin{array}{c}-0.003 \\
{[0.802]}\end{array}$ & $\begin{array}{c}0.005 \\
{[0.201]}\end{array}$ & $\begin{array}{c}-0.005 \\
{[0.636]}\end{array}$ \\
\hline Observations & $5,928,240$ & $5,929,693$ & $6,359,781$ & $5,498,152$ & $5,973,283$ & $5,884,650$ \\
\hline R-squared & 0.001 & 0.004 & 0.032 & 0.007 & 0.002 & 0.004 \\
\hline
\end{tabular}

Notes: Small exporters are firms with average exports over the entire sample period that is below the sample median. The remaining exporters are classified as large. First export in or before 2010 refers to exporters whose first export shipment was in 2010 or after. The remaining exporters are classified as having first exported before 2010. Infrequent shippers are exporters with average number of annual shipment days over the entire sample period that is at or below the sample median. The remaining exporters are classified as frequent shippers. All regressions include day-of-year fixed effects, day-of-week fixed effects, year fixed effects, and a constant that is not reported. Robust standard errors in parentheses are clustered at the day level. ${ }^{* * *} \mathrm{p}<0.01,{ }^{* *} \mathrm{p}<0.05,{ }^{*} \mathrm{p}<0.1$ 
Table 8: Robustness Checks

\begin{tabular}{|c|c|c|c|c|c|}
\hline & (1) & (2) & (3) & (4) & (5) \\
\hline Dependent Variable & \multicolumn{5}{|c|}{ Indicator for Exporter } \\
\hline Estimation Method & $\mathrm{FE}$ & & & $S$ & \\
\hline $\mathrm{H}_{\mathrm{t}}$ & $\begin{array}{c}-0.012^{* * *} \\
(0.002)\end{array}$ & $\begin{array}{c}-0.012^{* * *} \\
(0.002)\end{array}$ & $\begin{array}{c}-0.014^{* * *} \\
(0.003)\end{array}$ & $\begin{array}{c}-0.014^{* * *} \\
(0.003)\end{array}$ & $\begin{array}{c}-0.012^{* * *} \\
(0.002)\end{array}$ \\
\hline $\mathrm{H}_{\mathrm{t}+1}$ & $\begin{array}{c}0.007^{* * *} \\
(0.002)\end{array}$ & $\begin{array}{c}0.007^{* * *} \\
(0.002)\end{array}$ & $\begin{array}{l}0.006^{*} \\
(0.003)\end{array}$ & $\begin{array}{l}0.006^{*} \\
(0.003)\end{array}$ & $\begin{array}{c}0.006^{* * *} \\
(0.002)\end{array}$ \\
\hline $\mathrm{H}_{\mathrm{t}-1}$ & $\begin{array}{c}0.002 \\
(0.002)\end{array}$ & $\begin{array}{c}0.002 \\
(0.002)\end{array}$ & $\begin{array}{c}0.003 \\
(0.003)\end{array}$ & $\begin{array}{c}0.002 \\
(0.003)\end{array}$ & $\begin{array}{c}0.003 \\
(0.003)\end{array}$ \\
\hline $\mathrm{H}_{\mathrm{t}-2}$ & $\begin{array}{l}-0.001 \\
(0.002)\end{array}$ & $\begin{array}{l}-0.001 \\
(0.002)\end{array}$ & $\begin{array}{l}-0.001 \\
(0.003)\end{array}$ & $\begin{array}{l}-0.001 \\
(0.003)\end{array}$ & $\begin{array}{l}0.0001 \\
(0.003)\end{array}$ \\
\hline $\mathrm{H}_{\mathrm{t}-3}$ & $\begin{array}{l}0.002 \\
(0.002)\end{array}$ & $\begin{array}{c}0.002 \\
(0.002)\end{array}$ & $\begin{array}{c}0.002 \\
(0.003)\end{array}$ & $\begin{array}{c}0.002 \\
(0.003)\end{array}$ & $\begin{array}{c}0.002 \\
(0.002)\end{array}$ \\
\hline $\mathrm{H}_{\mathrm{t}-4}$ & $\begin{array}{l}-0.002 \\
(0.002)\end{array}$ & $\begin{array}{l}-0.002 \\
(0.002)\end{array}$ & $\begin{array}{c}0.000 \\
(0.003)\end{array}$ & $\begin{array}{c}0.000 \\
(0.003)\end{array}$ & $\begin{array}{l}-0.002 \\
(0.002)\end{array}$ \\
\hline $\mathrm{H}_{\mathrm{t}-5}$ & $\begin{array}{c}0.001 \\
(0.002)\end{array}$ & $\begin{array}{c}0.001 \\
(0.002)\end{array}$ & $\begin{array}{l}-0.001 \\
(0.002)\end{array}$ & $\begin{array}{l}-0.001 \\
(0.003)\end{array}$ & $\begin{array}{c}0.001 \\
(0.002)\end{array}$ \\
\hline $\mathrm{H}_{\mathrm{t}-6}$ & $\begin{array}{c}0.002 \\
(0.002)\end{array}$ & $\begin{array}{c}0.002 \\
(0.002)\end{array}$ & $\begin{array}{c}0.003 \\
(0.002)\end{array}$ & $\begin{array}{c}0.003 \\
(0.002)\end{array}$ & $\begin{array}{c}0.001 \\
(0.002)\end{array}$ \\
\hline $\begin{array}{l}\text { Cumulative effect }\left(\sum \mathrm{H}_{\mathrm{t}+\mathrm{s}}\right) \\
\text { P-value }\left(\mathrm{H}_{0}: \sum \mathrm{H}_{\mathrm{t}+\mathrm{s}}=0\right)\end{array}$ & $\begin{array}{l}0.0002 \\
{[0.973]}\end{array}$ & $\begin{array}{c}0.0002 \\
{[0.973]}\end{array}$ & $\begin{array}{c}-0.003 \\
{[0.630]}\end{array}$ & $\begin{array}{c}-0.003 \\
{[0.683]}\end{array}$ & $\begin{array}{c}-0.001 \\
{[0.825]} \\
\end{array}$ \\
\hline $\begin{array}{l}\text { Observations } \\
\text { R-squared }\end{array}$ & $\begin{array}{c}11,857,933 \\
0.203\end{array}$ & $\begin{array}{c}11,857,933 \\
0.002\end{array}$ & $\begin{array}{c}8,005,941 \\
0.001\end{array}$ & $\begin{array}{c}7,842,721 \\
0.001\end{array}$ & $\begin{array}{c}11,857,933 \\
0.003\end{array}$ \\
\hline
\end{tabular}

Notes: In column (1) we report the estimates from a version of the baseline specification that includes firm fixed effects. In column (2) we report the estimates of the baseline specification where the standard errors have been clustered at both the firm and day level. In column (3) we estimate an augmented specification that controls for the daily Baltic Dry Index while in column (4) we control for both the Baltic Dry Index and the daily global crude oil price. These data are not available for every day in our working sample, which is why the sample sizes in columns (3) and (4) are smaller. In column (5) we estimate a version of the baseline specification where the day-ofyear fixed effects have been replaced by month fixed effects and an indicator for a public holiday. All regressions include day-of-week fixed effects, year fixed effects, and a constant that is not reported. Robust standard errors in parentheses in columns (1) and (3) to (5) are clustered at the day level. ${ }^{* *} \mathrm{p}<0.01,{ }^{* *} \mathrm{p}<0.05,{ }^{*} \mathrm{p}<0.1$ 
Table 9: The Impact of Hartals on Export Value and Export Mode

\begin{tabular}{|c|c|c|c|c|}
\hline & $(1)$ & $(2)$ & $(3)$ & $(4)$ \\
\hline \multirow{2}{*}{$\begin{array}{l}\text { Dependent Variable } \\
\text { Estimation Method }\end{array}$} & \multicolumn{2}{|c|}{ Ln(Daily Exports) } & \multicolumn{2}{|c|}{$\begin{array}{c}\text { Indicator For Air } \\
\text { Shipment }\end{array}$} \\
\hline & OLS & Firm FE & OLS & Firm FE \\
\hline \multirow[t]{2}{*}{$\mathrm{H}_{\mathrm{t}}$} & -0.033 & $-0.037^{* *}$ & $0.031^{* * *}$ & $0.031^{* * *}$ \\
\hline & $(0.020)$ & $(0.017)$ & $(0.007)$ & $(0.006)$ \\
\hline \multirow[t]{2}{*}{$\mathrm{H}_{\mathrm{t}+1}$} & 0.017 & 0.028 & -0.013 & -0.004 \\
\hline & $(0.024)$ & $(0.022)$ & $(0.010)$ & $(0.007)$ \\
\hline \multirow[t]{2}{*}{$\mathrm{H}_{\mathrm{t}-1}$} & 0.019 & $0.039^{*}$ & $-0.014^{*}$ & -0.010 \\
\hline & $(0.022)$ & $(0.021)$ & $(0.009)$ & $(0.007)$ \\
\hline \multirow[t]{2}{*}{$\mathrm{H}_{\mathrm{t}-2}$} & 0.020 & 0.022 & 0.008 & -0.003 \\
\hline & $(0.019)$ & $(0.018)$ & $(0.008)$ & $(0.006)$ \\
\hline \multirow[t]{2}{*}{$\mathrm{H}_{\mathrm{t}-3}$} & 0.012 & 0.006 & -0.004 & 0.004 \\
\hline & $(0.020)$ & $(0.018)$ & $(0.008)$ & $(0.005)$ \\
\hline \multirow[t]{2}{*}{$\mathrm{H}_{\mathrm{t}-4}$} & 0.006 & -0.003 & 0.006 & 0.006 \\
\hline & $(0.020)$ & $(0.019)$ & $(0.008)$ & $(0.007)$ \\
\hline \multirow[t]{2}{*}{$\mathrm{H}_{\mathrm{t}-5}$} & $0.048^{* *}$ & $0.031^{*}$ & $-0.026^{* * *}$ & $-0.020^{* * *}$ \\
\hline & $(0.020)$ & $(0.019)$ & $(0.009)$ & $(0.007)$ \\
\hline \multirow[t]{2}{*}{$\mathrm{H}_{\mathrm{t}-6}$} & 0.007 & 0.022 & -0.004 & 0.006 \\
\hline & $(0.019)$ & $(0.017)$ & $(0.017)$ & $(0.020)$ \\
\hline Cumulative effect $\left(\sum \mathrm{H}_{\mathrm{t}+\mathrm{s}}\right)$ & $0.096^{*}$ & $0.109^{* *}$ & -0.017 & 0.011 \\
\hline P-value $\left(\mathrm{H}_{0}: \sum \mathrm{H}_{\mathrm{t}+\mathrm{s}}=0\right)$ & {$[0.090]$} & {$[0.019]$} & {$[0.400]$} & {$[0.481]$} \\
\hline Observations & 826,858 & 826,858 & 826,858 & 826,858 \\
\hline R-squared & 0.009 & 0.248 & 0.013 & 0.196 \\
\hline
\end{tabular}

Notes: The dependent variable in columns (1) and (2) are each firm's daily exports in natural logarithm. The sample in these columns is restricted to firm-day pairs with positive exports. The dependent variable in columns (3) and (4) is an indicator that takes the value of one if a firm uses air transport on any given day and is zero otherwise. The sample in these columns is also restricted to firm-day pairs with positive exports. All regressions include day-of-year fixed effects, day-of-week fixed effects, year fixed effects, and a constant that is not reported. Robust standard errors in parentheses are clustered at the day level. ${ }^{* *} \mathrm{p}<0.01,{ }^{* *} \mathrm{p}<0.05,{ }^{*} \mathrm{p}<0.1$ 